Sri Lankan Journal of Librarianship and Information Management Vol.4, Nos.,3\&4

(July-Dec.2011) pp. 1 -58

\title{
SRI LANKA's EARLIEST LIBRARIES - ANURADHAPURA And POLONNARUWA PERIODS
}

\author{
Russell Bowden * \\ *The Author is a Fellow of the Sri Lanka Library Association, an Honorary Fellow of \\ CILIP, Honorary Fellow of IFLA and Honorary Librarian of the Royal Asiatic Society of \\ Sri Lanka. He has a M. Phil. from the University of Kelaniya.
}

\section{Introduction}

The 'Period' in this work - for the sake of narrative convenience - starts with the arrival of the Arahant Mahinda in 246 B.C. (although Anuradhapura was founded at least one hundred and fifty four years earlier) and extends until circa 993 A.D. when the increasing numbers of invasions from South India caused the gradual shift of the capital to Polonnaruwa between the years 993 and 1038 A.D.. The narrative and examinations continue to King Parakrama Bahu's unification of the Sangha circa1164/5 A.D.

Processes of transmission of anything - be it vegetables from the farmer to the market to the housekeeper; from the car salesmen to garages to end-purchasers; from the writer to the editor, the publisher, the bookseller to the reader give cause for many considerations. From them questions are often asked with answers obtained to the satisfaction of the enquirer whose motivation is legitimate. Unfortunately, with regard to processes related to the importance of the transmission of the Buddha's Words comparatively few similar questions appear to have been asked - and, as a consequence, even fewer answers discovered! One has to wonder at this apparent lack of curiosity over centuries in a subject of such significance to a large proportion of the world's population - at least until contemporary scholars' commenced investigations in the midnineteenth century.

\section{Definitions}

It is necessary to differentiate very clearly between 'libraries' and 'archives' because differences are not always appreciated even though they possess very different functions. "In the strict sense of the term a 'library' is a 'collections of materials organized for use'. The word derives from the Latin word 'liber', a book. The Latinized Greek word 'bibliotheca' is the origin of the word for 'library' in the Greek, Russian and Romance languages. There is good reason to believe that the root concept of 'library' is deeply embedded in our ways of thinking about the world and coping with its problems. 
In its primary role as guardian of the social memory, there are many parallels with the ways in which the human memory orders, stores and retrieves information necessary for survival" related to "the instinct to preserve, the passion to collect and the desire to control dominant influences in the genesis and growth of the library idea in the history of civilization." (McGary, 1997: 254).

An 'archive' on the other hand is defined as "The non-current records of an institution, organization, business or person, created for working purposes and retained by the original creator, or a successor, for reference and/or historical interest. In many instances the records will have been sifted after a set period in order to retain only originals of primary significance. Archives may be in widely differing formats, including parchment rolls, bound volumes, paper files, maps, textiles, works of art, photographs. films, electronic archives, audio-visual materials, sound archives, microform and three dimensional objects. The term also applies to the buildings." (Forde,1997: 15).

Neither do the materials held in these store-houses clearly define the institution libraries hold old 'rare books' collections that also include manuscripts and incunabula much older than some that are in archives. Archives (as in Sri Lanka today) hold books. It is the function - the first collecting and organizing materials for more social use (education, cultural, literary and recreation) and the latter collecting usually 'official' records (for instance from governments, institutions and organizations) for preservation and use (mainly reference) - that primarily identify the differences. These distinctions need to be borne in mind.

Supporting these distinctions are two terms identified and applied by Chandra Wikramagamage and used in Sinhala - 'ganthakara-pirivena' referring to a 'mine of books temple' and 'potthakalaya' referring to 'library'. T G Piyadasa, quoting Paranavithana, suggested 'that the terms 'Pota' as 'Potaki' found on the Sigiriya Graffiti [that is later than 500 A.D.] may be equated with 'Potthakin' which means 'a keeper of books'. If so 'Bhandarapotthaki' may be equated to the position of that of 'Chief Keeper of books' and 'Adhipotthakin' to mean a Director of libraries, 'Bhandarapotthakin' compares favourably with 'Saraswathie Bhander' the Indian counterpart of these times. The library itself was referred to in India as 'Saraswathie Bhander' or the 'abode of the Goddess of Wisdom'." (Piyadasa, 1985: 14 - 15). Piyadasa also refers to "a kind of vihara popularly known as 'Potgul Vihara' (temple of the library'." (p.15). However, today, these seem to be over-romantic, cumbersome and no longer entirely acceptable translations [see Note 1 below].

Wikremagamage also refers, en passent, to the word 'dhammāgāra' but although a 'book' it was one that was entombed in buildings to serve as a focus for acts of worship. They were not usually manuscripts in the normally-understood sense but ornamented scripts engraved very often (like the Mahayana sutta fragment excavated by Ashley de Vos at the Jetavana) on gold plate and intended for praise and worship as were the Bodhi leaf, swastika and later images of the Buddha, rather than documents for everyday use. 
This practice is well described by Gunawardhana. "A more developed concept of 'relics' appears in two Sinhalese works, the Püjāvaliya and the Saddharmālānkaraya dated to the thirteenth and fourteenth centuries respectively. They speak of the Bo Tree and the dharmadhātu as 'foundations of the Buddhist order' (Sāsanapratiskha) which prevent the establishment of the authority of non-Buddhist rulers of the island. Moreover the Saddharmālamkāra mentions a type of stūpa, the dharmacaitya, where scriptural works like the Dhamsangunu (Pali Dhammasangani) and the Paticcasamputppāda were enshrined. The practice of enshrining fragments of the scriptures in stupas was widely spread throughout the Buddhist world . . . These deposits were known as dhammadhātu (dharma relics). ${ }^{1}$

The purpose in citing these examples is to indicate that the recorded Words of the Buddha for long occupied an important place in Lankan society but only for the purposes of worship and not, ironically, in manuscripts for use in libraries for study - as we intend to so prove.

The significant issues to note here are that whatever of this period are today described by some authors as 'libraries' these they were not: the collections that did come into existence (after 23 B.C.) in no way measured up to the definition of a 'library' as above. They were collections of manuscripts - neither more nor less!!! The same can be said also for 'archives'.

If this is the case then an answer needs to be supplied to the question: 'why then refer to 'libraries' and archives' here at all?' The answer to the first is simple. Writers and scholars have used both words with a freedom and facility that is as out of place as is referring (as, similarly, most scholars have done) to 'books' when books did not exist in Sri Lanka until the coming of the colonialists (for imported materials) and locally-produced books, using a Sinhala-cut type-face, which was not until 1737 (Bowden, 2004: 199).

\section{Sources of Evidence}

Today there are only three sources for the earliest evidences available to us. The first are those in the existing manuscripts available to us today. These can be placed in three groups - the vamsas or histories of Sri Lanka of which there are three primary sources - the Dipavamsa (today of doubtful historical validity) and, based on it, the Mahavamsa and the Culavamsa. The second are the Atthakathas or Commentaries. Related to these are the sub-commentaries to the Commentaries - the tikas. The second source is also written records but not in manuscripts (which are subject very much to the ravages of time) but recorded in

\footnotetext{
${ }^{1}$ The popularly labeled 'library' - the Potgul Vihāra - on the bund of the Parakrama Samudra in Polonnaruwa is much more likely to have been a dhammadhātu rather than a 'library' containing manuscripts for use and consultation that it is now popularly believed to have been "but the presence of stūpas clearly shows that this is a sacred building" (Wikramagamage 2004: 203) i.e. intended for worship.
} 
lithics and epigraphical inscriptions. The third source is what, in the past, has been discovered from the ground and today what remains in the ground waiting to be discovered by archeologists. Beyond these no other sources of evidences, of any reliability, can be expected to be revealed.

Lithic sources are primarily of two types, the inscriptions that were carved in stone (often on pillars) many of which still exist (and which, of course, weather better than manuscripts) and have fortunately drawn the attention of scholars so that they are known and recorded as in the Archeological Survey of Ceylon's 'Epigraphia Zeylanica'. The second are inscriptions on drip ledges over or inside caves in which the monks resided and other similar graffiti - the best-known of which are the poems on the polished wall (Kaetapath Pawura) at Sigiriya.

From earlier works of scholars and librarians we know that there is little enough in any of these sources that mention manuscripts ('books'), libraries, librarians and collections. Thus, in order to catch at any information, evidence, facts or clues, one has to cast one's net wide or, alternatively, dig very deeply.

\section{Histories - the 'Vamsas' (Chronicles): What do they reveal?}

In any research one should early turn to sources and these in most cultures are the chronicles ('vamsas') for details of events and facts. However, in our investigations they are suspected of being able to provide very little in the way of hard data because of the different purposes for which historical records in India and Asia were compiled from those that (later) developed in the West.

There are three significant ones that serve to underpin Sri Lankan contemporary society. The first, the Dipavamsa, need concern us little here because its credentials, according to Geiger - one of its earliest translators, are suspect. Its texts, over centuries, have become corrupted and its language no longer clear nor easy to comprehend. Nevertheless its significance should not be under-rated because (most scholars appear to agree) its genesis probably grew out of the atthakathas and so that it, in turn, provided the foundation for the later Maha- and Cula-vamsas. It was composed probably after 303 A.D. - which was long after the events with which it was concerned although the atthakathas, from which it drew much of its material, were likely to have been more contemporaneous. (Geiger,1912: xi). It is the two later works which, in far more detail and with greater reliability, cover the same period and major events. The Mahavamsa is likely to have been not only an up-date on the Dipavamsa but, as Geiger regarded it "a conscious and intentional rearrangement of the Dipavamsa." [XI] In addition Geiger, in his invaluable Introduction, does allow that its source could also have been the earlier work based on an atthakatha [p. $x$ ] giving it, despite the fact that it was composed more than 400 years after these events, a certain credibility. Nevertheless as a 'history', as understood today, composed to accurately and reliably record dates and facts - which on the whole can be entirely relied upon - it is not. 
It does not conform to the modern concept of an historical work as explained by the 'Father of History' - 'His' 'story' - the Greek Herodotus (born in the third quarter of the $5^{\text {th }}$ century B.C. and writing around 425 B.C. and therefore predating the periods in which we are interested). This is not surprising because Herodotus viewed history (indeed one might accurately suggest 'invented' 'history') from his perspective of recording time and place and activity. His period of activity was complemented by the Emperor Alexander's own historian Callisthenes, hired by him in the 348's B.C., by Cleitarchus circa 300 B.C. and later by Diodorus with his 'Library of History' at the end of the last century B.C. (Cartledge,2004: 102/3; 247; 255). Indian and Lankan historians in their compilations had very different motives. In the case of the Mahavamsa they were concerned to eulogise the period that Mahanama (its author) judged to be glorious - from the arrival of Prince Vijaya (483 B.C.) to Mahasena $276-303$ A.D. (Geiger,1912: $x$ ) - in Sri Lanka's early history. In the case of the Culavamsa's author (thought to have been Dhammakitti after 1165A.D. it was to glorify the achievements of King Parakramabahu I and particularly those associated with his relationship with the Sangha.

Geiger - assessing the problems of placing too much trust in the 'historical' aspects of the vamsas states when the time later came to compose his Introduction to the Culavamsa in 1928 - is forthright (and relevant to our problem) when he writes "Of much however, equally interesting [meaning not repairs by kings to cetiyas etc.] we hear nothing at all. .... Not what is said but what is left unsaid is the besetting difficulty of Sinhalese history." (Geiger,1912: v). To this we can only respond with a generous commendation based on the idea that what is said is of the greatest significance although what is left unsaid provides clues which - had we been faced with a complete vacuum of 'nothingness' - nothing could we possibly have gleaned! As will later be proved "what is left unsaid" will be of the greatest assistance to us. Geiger, after carefully considering the opinions of other contemporary scholars of his period, opines "The warning to handle critically, which the excellent historians considers necessary with regard to the Ceylonese Chronicles, is certainly justified" (Geiger,1912: xiii) and one can also assume that he included in the use of that plural noun, the histories or vamsas too. Nevertheless, approvingly quoting Windisch, "Here too the task of Science is to lay bare the grain of truth" (Windisch,1908: 4) continuing to correctly and significantly point out "those Chronicles contain no pure history. But they represent the traditions of their time and permit us to draw retrospective conclusions as to earlier periods" (Geiger,1912: xiii). They are grains in a great deal of chaff. But for modern researchers these 'grains', although they are few and far between, are nevertheless of the greatest assistance to investigations: for them, we must be most grateful as, indeed, we must also be for the excitement contained in many of the writings, the humanity and understanding shown of peoples' foibles and the very readability of many of these works. 
One of the Mahavamsa's prime purposes therefore was less to collect facts and dateable events than to eulogize what, looking back on the period from whence most of it was written by Mahanama (although the last verses of the last Chapter XXXVII were written by another, unknown, author (Geiger,1912: $267 \mathrm{ff1}$ ) in the reign of King Dhatusena (460 to 478 A.D.), that is about 150 years after the last events recorded in it) was already perceived to be a period of phenomenal Buddhist expansion and great developments based on social, cultural and societal achievements under specifically those whom the author considered to be the great kings of Lanka. His purpose is well-explained in the 'memorial verse' ending Chapter thirty-four "Thus men of good understanding, who have conquered pride and indolence, and have freed themselves from the attachment to lust, when they have attained to great power, without working harm to the people, delighting in deeds of merit, rejoicing in faith, do many and various pious works" (M-v. xxxiv. 94) although, as we shall later observe, this was often far from what actually transpired.

\section{Background - Historical Events}

It was in the relatively short second, restored reign of Vattagamani, of only twelve years, that two major events in Sri Lanka's history and Buddhist development occurred that could have impacted on the development of libraries. The first was the introduction of a new nikaya (and its buildings) to permit entrance into the conservative Theravada doctrinal beliefs of the Mahavihara fraternity of, what they considered to be, vaitulya heresies.

The second was the writing down of the pitakas that constitute the Canon. Related to this event it was noted that "two hundred and seventeen years ten months and ten days had passed since the founding of the Mahavihara" (M-V. $x x x$ iii 80 ) in 247 B.C. ${ }^{2}$ Nevertheless the exact dates are very difficult to pin down or to calculate with any reliability but it was in either 31,30 or 29 B.C. (in order to provide variances in the months) that Vattagamani constructed the Abhayagiri monastery. It was also under this king's rule that the major decision was taken to record for the very first time in writing the Words of the Buddha. Amazingly only the briefest mention of this momentous event is recorded in the Mahavamsa "The text of the three pitakas and the atthakathas thereon did the most wise bhikkhus hand down in former time orally, but since they saw that the people were falling away (from religion) the bhikkhus came together, and in order that the true doctrine might endure, they wrote them down in books." (M-v. xxxiii 100). That is all - 52 words in English - and nothing more! So, just as with the significant events of the First Buddhist Council, the important details of these most major events in the history of the development of the Tipitaka were passed over, in Sri Lanka, with almost ironical brevity and with an apparent lack of contemporary perception as to their significance.

\footnotetext{
${ }^{2}$ This is a most unusual statement given the normal lack of interest in dates and chronologies and one cannot but wonder about the purposes of it.
} 
No exact date for the writing down is provided and scholars appear to have argued between 90 and 19 B.C. However, given that the Abhayagiri monastery was not built until some time around 31 to 29 B.C. and the unquestionable need for it to get itself firmly established [in a relatively hostile religious and political climate prevailing at the time] the decision and thereafter the event of the writing down must have taken place some years afterwards - possible no earlier than in the period five years later and more likely about 10 years later - placing it much closer to 19 B.C. but probably even later than that i.e. between 10 and 15 B.C. [We have taken an 'average' date to fix it mid-reign in 23 B.C. which will adequately suffice for our purposes.] One of the causes of the redaction was a massive famine - known as the 'Brahmana Tissa Peril' - that provided one of the reasons for the decision - but even the date of that is open to later scholars' challenges and even the precise history of it is not always clear but seems to have shrouded itself in legends.

The third event was the translation of some of the suttas out of Pali into native Sinhala in the reign of King Buddhadasa between 340 and 368 A.D. by Mahadhammakathi. In comparison to the earlier event the vamsa has even less to record "In the reign of the same king the ascetic Mahadhammakithin translated the Suttas into the Sihala tongue" (C-v. 37. 176) - nothing more!

A careful examination of the texts of the Maha- and Cula-vamsas reveals astonishing records of double-dealings, sexual intrigues, spilling of blood, parricides, murders and deaths more akin to a contemporary western crimefiction novel and only bettered (if that is the correct word) by similar but far more bloody events by the kings of Burma intent in the same manner in ensuring secrecy into, and permanency for, the ways in which they secured their thrones. After such actions then kings' main objectives - in contradiction of the Buddha's teachings on karma, karmic consequences and cause and effect - were their attempts to absolve themselves. As a consequence the Mahavamsa indicates that with few exceptions, kings made large contributions to the Sangha (community of monks) through gifts, the construction of new buildings, repairs and the up-grading of older ones, with donations of monies, villages (and the villagers in them), tanks and irrigation canals etc. So one has the almost ironic juxtaposition of rulers lavishing wealth of all types on the Sangha and the relics and symbols of Buddhism in efforts to mitigate wrong-doings and yet providing nothing for the Words, themselves, of the Buddha or with acts or for institutions' establishments to improve comprehension of the Doctrine and its practices. Despite these abhorrence the authors of the Mahavamsa still believed that this long period of 551 years corresponded to the 'Golden Period' of the development of Buddhism and contributed to the establishment of the unified state of Sri Lanka (although it was not called that and the unity and achievements of which it so greatly approved proved to be anything but permanent.) Hence the work concentrates on what its author Mahanama, somewhat subjectively it has to be judged, considered to be significant developments in Buddhism and the development of Sri Lanka's history such as the establishment of religious 
buildings and caves at Mihintale', the preparation of the site for the Bodhi Tree from Bodh Gaya and its arrival in Sri Lanka and its delivery to the Mahameghavanarama in Anuradhapura (reported in two chapters of this thirtyseven chaptered work). Surprising is it too that the preparation of the Bodhi Tree and the off-shoot and its journey to, and welcome in, Sri Lanka are given such prominence - and described beautifully in the most poetic language - as symbolic of the Buddha's Enlightenment but the very words themselves of the Buddha are given, in comparison, almost no prominence. [Perhaps already $\left(5^{\text {th }}\right.$ century A.D.) so relatively early in the history of the development of Theravada Buddhism in Sri Lanka, were the relics and symbols of the Buddha provided with respect rather than his Teachings and the words of his Dhamma!]. In places the author gets carried away in his enthusiasm to exalt, as when he describes the overseas visitors to King Dutthagamani's laying of the foundation stone of what is today the Ruwanwelisaya where 14 visiting famous Theras are accompanied by, in total, one million four hundred and thirty-six thousand bhikkhus and ascetics with this figure not including the 'locals' about which the Mahavamsa disarmingly reports "As for the number of the bhikkhus dwelling in the island who met together from every side, no strict account has been handed down by the ancients." (M-v. xxix. 44) Enough was apparently enough!

It is, in Geiger's translation, immensely and easily readable and portions of it are exciting to read - for instance the march of Dutthagamani against the Damilas and the eventual defeat of Elara and then the King's anguish at the countless numbers killed. Even more emotionally moving is the death of Dutthagamani before the completion of his works. Equally enjoyable, from its first introduction in Chapter XVII onwards, are the closing verses to every chapter each containing a parable or a spiritual or moral comment in what Geiger refers to as a 'memorial verse' (Geiger, 1912: 267 ff 1).

\section{Five 'Great Commentators'}

The fourth historical event relevant to the development of libraries occurred during the reign of king Mahanama with the arrival of first Buddhadatta followed speedily by the greatest, Buddhaghosa and then the involvement of Dhammapala, Upasena and Mahanama between circa 410 and 590 A.D. In this period these five (of whom two were Sri Lankans) created twenty-one or twentytwo works. The objective was little concerned with Lanka but with Venerable Revatta's instruction to Buddhaghosa to return back to India, from whence he came, with the Commentaries (Atthakathas) to the canonical texts, where the latter had remained extant whilst the Commentaries had been 'lost' but were still available in Sri Lanka, mainly in Sinhala. This was his (and later the others') purposes. It was not to add to the availability of literature and manuscripts in Sri Lanka. Although this, incidentally, is what did happen. 


\section{The 'Librarian' in Buddhism}

I have suggested elsewhere that "The Canon indicates that the Buddha is not known to have referred to the concept of 'librarian' but that is hardly surprising in a society where writing was little used for recording information and not at all for the holy words of the Vedic philosophers. These, and later the Dhamma, were all considered to be sirti, or sacred, therefore only to be spoken and heard, originally, by the few. Few, if any, libraries as a consequence are likely to have existed in India and Sri Lanka before the life-time of the Buddha. Nevertheless if the skills of Librarians are in the collection, organization and making available of information then one person stands out above all others as coming as close as was then possible in that time to being the Buddha's Librarian or 'Librarian of the Dhamma'. That person is the Arahant Ananda. The Buddha came close to using the term 'librarian' of Ananda when he referred to him as the 'Dhamma bhandagarika' or 'treasurer of the Dhamma'. The Anguttara Nikaya Atthakatha lists five qualities that Ananda is said to have possessed that gave him the right to this title: erudition, attentive memory, behaviour, resolution and personal attention (Anguttara Nikaya Atthakatha; 286ff). It is confirmed in the Mahavamsa where Mahanama [its translator], reporting in his inimitable fashion on the First Buddhist Council, stated "Then the thera (Mahakassapa) taking (the task) upon himself questioned concerning the dhamma, him the chief of those who had most often heard (the word), him the treasure-keeper [note 6] of the Great Seer (the Buddha); and the thera Ananda, taking (the task) upon himself ... expounded the whole dhamma" (III 35) with note 6 explaining "Kosarakkha, according to the Tika = dhammabhandagarika, i.e. treasurer of the truth or the true doctrine." (Bowden, 2006: 17).

\section{Four periods of development}

This period of our interest, of approximately 1,400 years, can be conveniently divided by events other than simple Mahavamsa-style chronologies and dates, using four major events to divide the period into sectors in which to examine in more details happenings that could have impacted on the developments of manuscripts and from them their collection and then libraries. These are: first the period of the establishment of the Sangha and the Theravada Doctrine - from the arrival of Mahinda (in 247 B.C.) to the writing down for the first time of the Theravada Canon (last quarter of the last century B.C.); the second - the first translation of some of the Theravada Suttas out of Pali into Sinhala (between the years 341 and 370 and most probably in 211 / 212 A.D.); the third period from this time until the arrival and work of the commentator Buddhadhatta (before 420 A.D.) and Buddhaghosa's work on the atthakathas into Pali and the commentaries of the other four commentators. The fourth period covers the years when the capitol was moved and Polonnaruwa was developed into a city by firstly King Vijayabahu I and then by King Parakramabahu I between 1056 and 1153 A.D. 


\section{Expansion of Manuscripts}

The Alokavihare redaction, or writing down, for the first time ever by any Buddhist sect, school or nikaya, of the Buddha's words - heretofore held to be sacred apart from being a major event of historical importance in the development of Lankan Buddhism would have also represented a major factor in the growth and development of the availability of manuscripts and therefore the ability to develop collections of them which eventually could provide the foundations for the later development of libraries. For the first time the Buddha's teachings did not have to be painfully learned and held in the minds of monks. Instead they could be referred to as inscriptions on palm leaves. From that event, one can be certain, a steady flow of manuscripts resulted. As a consequence too the Alokavihara probably would have developed into the equivalent of a scriptorium - a sort of factory constantly copying and producing a steady output of canonical manuscripts - something that had never even been imagined before. These activities, consequently, created an increasing demand for the safe storage of manuscripts and thereafter a need for the arrangement of them in some order so that they could be retrieved, with facility, for use: the genesis of the techniques of librarianship!

Thereafter, with some of the prohibitions on copying the Canon into manuscripts removed, further incremental expansion would have taken place through the succeeding years. Not all restrictions however would have gone. The Mahavihara remained rooted in its traditionalism and conservatism. Writing down occurred, not in the capital city close to the Mahavihara, but at a little-known site ninety-five kilometers south-south east of it. It also came about under the leadership of the liberal Abhayagiri monks along with the king's greater support of this monastery than the former. That expansion in the availability of the numbers of manuscripts continued there can be no doubt as suggested by Malalasekera and Adikaram the former suggesting that "Manuscripts of the Alu-Vihara edition were soon made and deposited in the Maha-vihara and other principle temples of the island" (Malalasekera,1994: 47).

Visiting Chinese monks (from the early $4^{\text {th }}$ to the $7^{\text {th }}$ centuries) created relatively accurate records (that are still extant today) of what they observed. They further verified such facts with the result that reports on the Mahavihara monastery collection and the establishment of the so-called vaitulya monasteries' collections that, today, we possess serve to provide incontrovertible evidence of their existence.

Manuscripts' growth is likely to have gathered further momentum after the next equally major event - the translation of some of the suttas from Pali into Sinhala between 341 and 370 A.D. during the reign of King Buddhadasa by Mahadhammakathi. That, beyond the confines of the Court, government, officialdom and the clergy, there were many people who could read these newlytranslated and available texts is probably to be doubted. Nevertheless their greater availability and the fact that these manuscript texts contained such 
valuable words as the Buddha's own, now available in a language easily comprehended, could not but have fuelled and increased demands for them and also have improved the abilities of teachers to instruct and their students to learn from usage of them.

Adikaram harboured the belief that after Mahinda brought the Pitakas to Sri Lanka few, if any, changes to these sacred canonical texts were made to them. "Though the Pitakas were committed to writing as late as the first century B.C. there is not sufficient reason to believe that they received any substantial additions after they were brought to the island by Mahinda" (Adikaram,1946: 134). The single exception that he allows is of the Vinaya (which could be expected to change as societies and the Order and situations developed). Nevertheless, only a few lines, later he qualifies this statement by allowing that even if there were changes made a record was kept of them "Whenever an addition to the Canon was made by the Sinhalese bhikkhus, care was taken to record that fact in the Commentaries. An example of this nature is seen in the Sumangalavilasini which says that the verses beginning 'Atthadonam cakkhhumato sarinam' of the Mahaparinibbana Sutta of the Dighanikaya were composed by the Theras of Ceylon" (134). This later, apparent volte face, of Adikaram apparently receives the support of Oliver Abeynayake who, in a relatively recent paper, argues that there is substantial evidence to prove that changes (not only to the Vinaya texts) but also that other additions were made to texts that apparently had been sanctioned by the Putaliputta Third Council in 247 B.C. and citing as proof "The fact that there are four stanzas authored by the Sri Lankan monks in the Sammaditthi Sutta of the Majjhima Nikaya" (Abeynayake, 2000: 63-183).

Another and, of course, primary body of users would have been the Buddhist clergy. Having the very teachings and doctrines and words of the Buddha immediately available in a language that a monk, with no difficulties, could understand because for the first time it was available to him in his own mother tongue - Sinhala as opposed to Pali although those language texts continued to exist in parallel. - would have represented a major intellectual development to assist with teaching and instruction that would have assisted the understanding and spread around the Island of Buddhism. Coupled with the writing down of these Words only about 350 years earlier (approximately seventeen generations earlier applying parampara time criteria) this event also must have created an increased demand from monks (and from educated lay people) for manuscripts. Their storage and organization for use would also have necessitated the development of the techniques of librarianship - however rudimentary these may at first have been.

This growth of the numbers of Lankan manuscripts would have continued fueled by the increasing copying and creation of texts necessitated by learning and teaching and merit-earning acts. In addition, monks visiting Sri Lanka from other countries and nikayas would have required sight of them to further and satisfy the 
educational and other reasons for which they had come to Sri Lanka. From beyond Sri Lanka's shores monks would have imported foreign-created manuscripts to meet the needs of liberal-scholarship in the vaitulya-based (although nominally remaining Theravada) monasteries like Abhayagiri. Thereafter they too would have facilitated the creation of the Jetavana-nikaya (circa 312 A.D.). That there would have been demands for them cannot be disputed although it is unlikely that authored texts from Mahayana-affiliated nikayas in India would have created similar manuscripts until well into the first century A.D.

Associated with the vaitulya-based problems would have been the Sri Lankan monks involved with, and suffering from, the 'putting down' of institutions ('destruction' probably being too strong a word to be used for the suppression of institutions which although representing ideas that were unacceptable to the primary temple in Sri Lanka, were still in the main, based upon the words, the teachings and the Doctrine of the Buddha as perceived by Theravadins). Given the strong possibilities that manuscripts were destroyed in these events, possibly by burnings, then the almost unbelievably speedy regeneration of these vaitulya nikayas (which we know occurred at phenomenal rates) would have led to demands for even more manuscripts to be created from un-destroyed copies. We particularly identify these events because there must have been deep concerns amongst the Mahavihara monks at the increasing influences of these vaitulya nikayas which would to some extant have been as a result of Mahayana ideas traveling down from the north and infiltrating the thinking of the monks in these Anuradhapura institutions via the texts that were brought by the traveling monks. Those in receipt of them - learning from painful past experiences - would not have been ignorant of the need to speedily have copies of them made as insurances for the future and available either immediately for use or for hiding in safe places against the days, after the 'put downs' had again occurred, to be available for re-copying!

Over periods of time, after the texts of the canon had been transferred for the first time in Alokavihara onto palm-leaf manuscripts then the opposition to such a situation, as represented by the conservative and ever-protective monks of the Mahavihara, would likely have altered so that the restrictions that had applied earlier would have been - if not removed - at least relaxed. Copying, although not on the scale of the mass-production of texts (as represented by the innovative invention of printing from moveable type in $15^{\text {th }}$ century Europe by Gutenberg) without Sangha restrictions and barriers, could then be increased. It did. Copying not only in Alokavihara could then take place in the avasas both as learning / teaching experiences for the student-monks but also as merit-earning exercises. So, just as with the advent of printing from moveable type, (invented by Johann Gutenberg in Strasburg and then his working in Mainz with Fust and Schoeffer just before 1450 and then with printing on a commercial basis later (in 1576) in Westminster Abbey in London by William Caxton) in Europe, there resulted in what would have seemed to have been a comparative avalanche of manuscripts. 
(Lock, 1958; 284 \& 73). Just as the social and political impacts in England and on Christianity in Europe, of Gutenberg's invention, were tremendous so in a much smaller way was the impact of the redaction at the Aloka Vihara on the spread of the Buddha's words in Sri Lanka. "In 1450 [that, of course, was a millennium and a half after the redaction] all Europe's books were hand-copied and amounted to no more than a few thousand. By 1500 they were printed, and numbered in their millions. Printing with moveable type ... was an invention waiting to happen." [Man (2002) back cover]. Equally plausibly, it could be argued, was the writing down of the Theravada canonical Buddhist scriptures, as another revolution waiting to happen!

The penultimate event, commencing the third period between 410 and 590, was characterised by the works of the five commentators who, as we have previously noted, did not have as their main objective the creation of Lankan literary artifacts but the replacement in India of lost atthakathas.

The last period, between 600 and 1165 A.D., is represented by the moving of the capital city from its ancient site in Anuradhapura, over periods of years, to Polunnaruwa and the building there of a planned and designed city from a relatively remote fortress guarding the fordable crossings of the Mahaveli River that constituted the boundary between Rohana and Rajarata and the construction in it of the great Jetavana university.

That this comparative increase, during these periods, of the creation of manuscripts ever ended, with an event that might provide us with a convenient cut-off date, there is no proof. Neither is there any reason to presuppose that it did. Just as, today, there is an unceasing demand for books so one can reasonably assume was there an unceasing demand for manuscripts once they, and what was inside them, had become more readily available. Indeed both Adikaram and Godakumbure point to the development of Sinhala literature that could not have materialized had there not been facility to create the manuscripts and documents in which these works were later recorded and made available.

\section{Library Buildings - Homes for Materials}

Libraries world-wide have traditionally housed 'documents' in whatever format or manner prepared. These have ranged from clay tablets, papyrus, parchment, palm-leaf manuscripts to paper-based books and today videos, CDs and DVDs. The format is relatively immaterial. The significance of all of these artifacts is with what is contained in them. These, of course are, in the main, words that convey information within those formats. In the history of the development of Buddhism in Sri Lanka it is the words that have always assumed priority and these words have imparted information which, in the main, has been versions of the Dhamma. When this has been challenged, as it was by those believing that aspects of them were heretical, it is has been the carrier of those words - the manuscripts - that have suffered. 


\section{Libraries}

Looking to the last half of the B.C millennium and the first half of A.D. a library, as a concept (although a library, as we might recognize one today, it may not have appeared to have been) was not new to the world (even though such an organization probably would have been strange in India during the time of the Buddha). More likely would it have been, what today would be more appropriately recognized by its function as, an archive having been established to collect together materials with the objective of their not being lost to mankind through destructions of whatever sort. One of the first, and without doubt one of the most famous, was the Library of Alexandria. Its purpose was the collection of documents and materials created from everywhere in the then-known world which essentially was that of the 'Greeks' [although at that period such a concept of 'Greek-ness' in the then independently and frequently warring existing CityStates of that geographical area did not exist].

This Great Library of Alexandria, created by Emperor Alexander the Great, was to come into existence just 232 years after the birth of Prince Siddhartha. This was during the period when, in India, the bhanakas were embarked upon their almost unbelievable intellectual feats of scholarship, analysis, synthesis, investigations and the creation of new works for the Pitakas as well as some Atthakathas - all amazingly achieved without the writing down of a text - so of no use to this Alexandrian Library! The objectives of that Library were to collect, within its walls, all literatures that had been created from the entire then-known world which stretched in the west from Italy and Sicily and north Africa (Egypt) across 'Greece', Turkey, the entirety of the Persian Achaemenid Empire [embracing lands far greater in extent than today's Iran ] - all the way from southcentral Europe to beyond the Indus and eastwards and from the south of Europe through the civilisations in Egypt and along the northern coast of Africa; from the steppes of Central Asia through Mongolia into China and Tibet and along the Oxus, Tigris and Euphrates rivers to embrace the great civilizations of Persepolis, Chaldean Ur, Babylon, Aleppo and on westwards and southwards to the Mediterranean and Indian Oceans. Given the existence and great use of the Silk Road and its 'feeder' off-shoots - up northwards towards the Gobi desert through Dunhuang and Turfan, and Khotan, and the Altai Mountains - and southwards via Kashgar and Balkh towards Tibet and to Srinagar and down the Indus River (Whitfield, 2004)] - this Great Library's existence could not but have been known to scholars in India very soon after the time of the Buddha. After all it was named (later) after the city in which it was created (in 331 B.C.) by the very emperor and conqueror Alexander the Great who was, himself, to arrive at the threshold of Buddhist civilization on the Beas River in 327 B.C. (near today's Amritsar) - only 156 years after the Buddha's passing away in 483 B.C. En passent one cannot help but comment on these events, so momentous in the development of the world's civilizations and cultures that took place geographically and chronologically comparatively so close to each other, but with no indications today that any of them was much aware of what was developing 
relatively close by the other - graphically expressed by Bhikkhu Bodhi in his Introduction to the Milindapanha "The Milinda is the product of the encounter of two great civilizations - Hellenistic Greece and Buddhist India." (Bodhi,1993: 13).

Legend has suggested that Sariputta it was who, before predeceasing the Buddha, established what was to become one of the greatest Buddhist seats of learning in Nalanda not far along the road north from Rajagaha. Even in the Buddha's time it "was already an influential and prosperous town" in which "Sariputta uttered his 'lion's roar', affirming his faith in the Buddha, shortly before his death" (Malalasekera, 1983: II 56). The northern tradition goes further in its believe that it was also Sariputta's birthplace (II 57). The tradition accords comfortably with the legend. However it is most unlikely, in those earliest days of its existence, that it possessed the three magnificent multi-storied buildings for its libraries that Hiutn Tsiang alleges existed during his visit circa 629 A.D. (Beal, 1884: 110 \& Beal, 1911: 109).

In those earliest of days there would have been no sacred literature to store because none of it - Vedic, Jain or Buddhist - was permitted to be written down by its 'protectors' anxious to maintain their grip on power that the holding back of information gave them (and today still does!) - purvokti as then it was. Nevertheless other cultures were less prohibitive (witness the need for the Alexandrian Library only 250 years later) and anyway that there were written documents, even if not of a sacred type, i.e. letters, (for instance King Tissa's letter to the Emperor Asoka with regard to his adopting the title 'Devanampiya'), administrative documents, inventories and accounts [witness the engraved and decorated walls of various entrances to the palace at Persepolis, the home of the Persian Emperor Darius the Great circa 522 B.C.] has not been challenged. So although library buildings may not have been a requirement for the earliest temples and monasteries in India and Sri Lanka they were to become necessary later - after 400 years and after the Theravada Canon had come to be recorded in writing on manuscripts in the waning years of B.C.

\section{Manuscripts and Libraries - Sources and References}

Godakumbura in his 'Sinhalese Literature' (1955) refers, for his research, to two primary sources "There are only two reliable catalogues of literary works in the Sinhalese language, both by Wickremasinghe, namely, the 'Catalogue of Manuscripts', and the 'Catalogue of Printed Books in the Library of the British Museum'. The number of manuscripts included in the first catalogue is very small . . . [after - correctly - disparaging W.A. de Silva's 'Catalogue of Palm leaf Manuscripts in the Library of the Colombo Museum' he continues] . . F Far more reliable are the lists of books made by Upham, Westergaard, De Alwis and Louis de Zoysa." (Godakumbura,1955: vii). D'Alwis worked around the 1870's and Wickremasinghe, appointed to complete D'Alwis' and de Zoyza's works by the British Colonial Government, completed his work on the Colombo Museum catalogue in 1896 and the British Museum catalogue in 1900. (Bowden, 2004: 208). 
Since then, of course, librarians and scholars have been at work to record and comment on what remained, on what was or had been available in the form of collections. The most recent and most notable being K.D. Somadasa's comprehensive 'Catalogue of the Nevill Collection of Sinhala Manuscripts' in seven volumes in the British Library (published between 1989 and 1995 by the British Library and the Pali Text Society).

Few other efforts have been made to reliably identify sources. The results have been unsatisfactory and the evidence unearthed slim in the extreme and the deductions drawn from them flimsy and unsubstantiated. Most of the works have centered on listings and the compilation of catalogues of available manuscripts. An earlier bibliophile's work compiled in Burma in the $18^{\text {th }}$ century was what Law called a 'sort of library catalogue' - the 'Gandhavamsa'. Around the same period, or earlier in Sri Lanka, James D'Alwis (circa 1869) and Louis de Zoyza (1876) were understandably more concerned to list and catalogue existing manuscripts before they vanished due to the vagaries of time, the climate and predators. The listings that they compiled are, for scholars today, invaluable but their bibliographical interests in where the original manuscripts had come from, how they had been adapted or changed and where they had been kept were nil. Also these earliest recorders were not at work until the second half of the $19^{\text {th }}$ century - many centuries after the periods in which we are here interested. (Bowden, 2004: 208). However there is evidence that de Zoyza had some feelings towards the genesis and safe-keeping of these manuscripts and obviously had some sense of history and thus of loss when he wrote scathingly in 1876 "It is most unfortunate that this investigation [one that James D'Alwis left uncompleted upon his early death] was not conducted at an early period of British rule when the monasteries were presided over by men of learning or at all events by men who highly valued their literary store. Since we occupied the Kandyan country (Kandaudarata) we disassociated ourselves altogether from Buddhism and in my opinion, very improperly allowed temple property to become prey to spoliator, the old class of learned priests has generally disappeared and has been replaced in many instances by men whose only object is to enrich themselves as fast as they can. From this cause thousands of valuable manuscripts are supposed to have perished, either by the devastation of white ants or the climate." (de Zoyza, 1876: 56) They are sentiments, more than a century later, that today Librarians ought to be able to share - and, more significantly, to do something about!!!

It is at this stage worth noting that neither Adikaram (1945), Godakumbura (working 1953-4) nor Gunawardena (in the 1960's), make any mention of the apparently significant work that pre-dated their studies - the Gandhavamsa (or 'History of Books' - Winternitz in 1907) created by a Burmese in the eighteenth century and critiqued by Minayeff in 1886 (Minayeff, 1886: 54) and published in 1943. Law refers to it as 'a sort of library catalogue' (which it was not - it was apparently a somewhat basic bibliography) but more correctly described by Law as a 'small and interesting outline of the history of Pali books' (Law, 1933: 576). 
That it was in existence during these scholars' research periods there can be no doubt. However, of course, without on-line access, it is possible that these scholars either did not know of its existence or that they all inadvertently overlooked it because for some reason or another, as an alleged authoritative text, it had fallen out of favour and had become forgotten. Although composed in Burma whoever was its author (Mahathera Dhammakitti of the city of Pulatti" (Law,1933: 568) or Nandapanna (Winternitz,1907: 211)) he must have had a considerable knowledge of Sri Lankan sources as he refers to the Kurundi and the Mahapaccari Sinhala Atthakathas as well as to the poranas and acariyas.

\section{Libraries - as perceived by contemporary Librarians}

As for the results of investigations by those in the profession of librarianship of likely, or possible, early collections and / or libraries little that is flattering can be stated. Far too often, in the few works that have been undertaken, sentences make use of the perfect infinitive tense of a verb such as 'ought', and phrases such as 'might have been', 'must have been', 'it is possible / probable that' etc. Such words in scholarship mean nothing. In scholarly works they are to be eschewed. In any event little enough rigorous librarianship research has been initiated.

One of the first contemporary observations about the early existence of libraries to appear was not until 1975 in an article by Tilak Kularatne "History of libraries in Sri Lanka". In it he wrote "The copies of these commentaries [referring to the Sihalatthakathas] may have been deposited in the Dighasandasenapati-pirivena at Anuradhapura which was given to Mahinda Thero by King Devanampiya Tissa. Later, when the Maha Vihara became the centre of Theravada Buddhism [in the on-going rifts between it and the monasteries representing the vaitulya or 'heretical' nikayas (schools),] it most probably would have had a library attached to it." (Kularatne,1975: 194). [This Author's italics].

Next, in 1985, was T. G. Piyadasa's "Libraries in Sri Lanka. Their origin and history from ancient times to the present time". He reserves only 19 out of a total of 104 pages - less than one fifth of his work - to this most important period employing phrases like "The Aluvihara edition would have formed the nucleus of the monastic library" [Author's italics] - and with no consideration of how this could have been nor even explaining any concept of the 'monastic library'. (Piyadasa, 1985: 3). He is followed by a non-librarian's - a historian's - opinion, (de Silva 1987: 46) who wrote "Many famous libraries had emerged in and around Anuradhapura and Magama either attached to the Mahavihara or the Abhayagiri fraternity" with, unfortunately, no evidence whatsoever to support such statements. Most recently R. H. I. S Ranasinghe published "Parani Lankawe Potgul Sampradaya" (Ranasinghe, 2006). The same problems of hypothecations appear in this Sinhala language work as in those written earlier in English except in this work Ranasinghe commences with a useful chapter listing the sources - especially the more ancient ones - that she consulted. 
It is most helpful. Thereafter amongst the 'oughts' and 'might have beens' and some unsubstantiated hypotheses she does discover heretofore unknown facts that have proved to be useful - as we shall later indicate and happily reference. To summarize: that is all that has existed - four works specifically devoted by library professionals and historians to the subject over a period of 2,000 years!

This earliest period witnessed no Buddhist Canonical texts from any schools in written forms. The Theravada Canon represented the first texts of any of the Buddhist nikayas to be so recorded. Without 'books', more exactly 'manuscripts', because books were not to make an appearance in Sri Lanka until the Dutch established a Press capable of printing from moveable type in 1736 in the Castle in Colombo (Bowden, 2004: 199) there could have been no collections and therefore no libraries.

If, more than two thousand years ago - from sometime in the last century B.C. 'books', or 'manuscripts' [to give them their correct descriptions] were created in the monastery or temple at Alokavihare in the earliest days of the redaction, but later also in other monasteries, where were they placed and stored in the caves at that first venue immediately on completion of the copying processes (i.e. ganthakara pirivenas); how were the manuscripts kept and how were they preserved? On removal from the Vihare, to other more permanent places (i.e pustakaliya), where were they stored, how then were they identified or (in modern terminology) how were they catalogued, classified and arranged and how were they conserved and preserved; how were services provided to subsequently make them available to users? These are routine questions that today any competent Librarian would ask so there is every justification to ask them now, in the $21^{\text {st }}$ century, of these ancient materials.

Answers to these and related questions, unsurprisingly, are few and not easily discovered. For a culture that highly prized words - particularly the Words of the Buddha and of those in Pali in the Theravada Canon - and for people - primarily monks - who gave so much of their lives to preserving and to propagating the Word of the Buddha (in whatever format preserved in these earliest days) and then later, by the turn of the millennium, for the first time recorded with some promise of permanence in print for posterity in documents, there can only be an expression of surprise at this apparent lack of interest. More amazing is the apparent lack of any interest in the intervening two thousand years not only to the formulation of questions about these problems and then to obtaining answers to them but also from professionals who practice the skills and tasks of librarianship to discover more about the genesis of the very earliest libraries and their contents in Sri Lanka. 


\section{Earliest Manuscript Collections and Libraries in Sri Lanka}

There would be no purpose in creating libraries if there was nothing to put into them. With regard to the Words of the Buddha (brought to Sri Lanka by Mahinda circa 246 B.C. there were no documented and written texts available for such conservation, storage and usage in any collections until almost the turn of the millennium from B.C. to A.D. His Words remained śrti - to be spoken and heard only. There were however other works that could legitimately have been expected to have found places in manuscript collections in monasteries or temples. Most unlikely would it have been to have expected in this period that collections of manuscripts were created elsewhere other than in religious institutions except documents of an administrative nature necessary for the rule and management of the government. These would have been associated with the King and his court and therefore his palaces. Merchants too, especially those trading beyond Sri Lankan shores, might be expected to have possessed manuscripts such as accounts, lists of traded goods etc. But that these had been collected together into anything today resembling a library (or an archive) is beyond imagination and no facts exist to suggest otherwise.

Nevertheless works that might be described of some literary merit do appear to have made an appearance reasonably early in this period. Literary works might have deserved libraries to preserve their contents.

No manuscripts relating to that category of works in this period exist today. However what is this period constituted a 'work of literature'? Godakumbura, in examining the earliest 'literary' creations judges that they were works that scarcely could measure up to a description at that stage of their development as 'literary works'. (Godakumbura,1955). He suggests that many texts were not unique creations but were instead derivatives from Tamil, Telegu and Malayalam translations often into a mixture of Pali and Sanskrit and with Sinhala, where used, in the ancient Prakrit form of Elu and written in the Brahmi script. Rather than being works of original literary creation many apparently would have better compared with what used to be designated as 'students' cribs' such as those used for swotting for Eng. Lit. for ' $O$ ' and 'A' levels. Others were glossaries and lexicons [to assist with language difficulties], teacher / student guides more akin to students' textbooks. Godakumbura assesses fairly accurately one might assume when he states "At a time when reference books were rare and the duplication of books difficult, students of a subject and even teachers preferred committing to memory the material they needed. Verse was easier than prose to memorise [hence the dual verse and prose structure of the Jātakas with the former considered canonical and the latter not so] and hence we get manuals on such subjects as grammar, rhetoric and alankāra in verse, or some other literary form which is more easily committed to memory." (Godakumbura, 1955: 335). An opinion supported by Malalasekera "Even today great respect is shown to the man who carries all his learning in his head' for 'who knows whether books may not get lost or destroyed and become not easy to lay hands on" (Malalasekera, 1994: 45) but who only, a couple of pages later, opines "And this writing down of 
the literature helped its advance in great measure; for a written literature can develop in a shorter time than one that is handed down by word of mouth, when each single text requires generations of teachers and disciples to be preserved at all." (Malalasekera, 1994: 47)

They were far removed, Godakumbura assesses [and we have noted], from classification as 'works of literature' that he suggests did not 'flower' until centuries later. It is an opinion not shared by Adikaram. He believes, instead, that a 'flowering' of Sinhala literature took place as early as the reigns of Mahācūli Mahātissa (17 B.C. to 3 A.D.) terminating in the reign of Bhātika Abhaya (38 to 66 A.D.) (Adikaram, 1946: Part II Chapter 5 "The first literary period"). This would have been soon after and therefore possibly related to the benefits of having canonical texts available in written format for the first time. Godakumbura assesses that there were two 'flowerings' - the first in the reign of Mahinda IV (975 - 991 A.D.) and the second in that of Parakrama Bahu II (1153-1186 A.D.). In contrast Law (in 1933) believed that there was one - but an extremely long one - from the $2^{\text {nd }}$ century B.C. until 420 A.D. and the commencement of work by Buddhaghosa. Gunawardena (in 1978) places it from Sena l's reign (833 to 853 A.D.) to around the $1200 \mathrm{~s}$.

Whatever the judgment one applies to these categories of works (students' texts, teachers' guides, glossaries, lexicons and other similar works) they would have had a legitimate claim, if not as works of literature, at least as 'teaching / learning tools' in the educational processes that were underway in the monasteries. Although not works of great scholarship, literary innovation nor of soul-inspiring creative merit they were important adjuncts to the teaching / learning experiences of a period in which Buddhism in Sri Lanka was undergoing great developments. They were, in the majority, 'working documents' created with the objectives of assisting monks with their audiences - the majority of whom would have been relatively new to the subject - to better explain and advise on teachings, doctrines and other Buddhist matters that were only available to the monks (until the translation from Pali into Sinhala of some of the Tipitaka suttas around 211 / 212 A.D.) in a language that was increasingly going out of use and that was getting increasingly large numbers of 'non-comprehenders'. These 'working tools' would most certainly have been most legitimate occupants of monks' cells. These, one can therefore surmise preceded other manuscript creations that later would fall into the category of Sinhala 'literary creations'.

From the creation of these 'working tools', as with the bhanakas in northern India those two centuries earlier, so again later in Sri Lanka, the creation of these simple glossaries, dictionaries, glosses etc on particular suttas and Buddhist texts, cyclopedias etc led to the creation, not this time of the Abhidhamma Pitaka, nor of the atthakathas in Pali but, in this case, of the Sihala Atthakathas. These, in no way, fail to meet criteria as 'works of literary merit'. Whether, and at what stage, these Sihala Atthakathas came to be written down is not clear. Because the words used in them were not canonical - had they been they would have had 
to follow the śrti strictures laid down for religious texts - there might, therefore, have existed substantial lee-way and tolerance in what could be inscribed, for these texts, onto manuscripts. In theory, at least, therefore they were open to being written down earlier than the Tipitaka texts because they did not have the śrti prohibitions placed upon them. However, they may not have been written down in their entirety but, possibly, only in note form. Reading between the lines of Godakumbura and Adikaram both authors seem to have harboured these beliefs - even if not actually stating them - that probably they had been recorded in manuscripts - if not in their entireties at least in memorable portions for exactly those purposes - as aides memoires.

The point to understand from these assumptions is that were the words comprising these works to have been written down earlier than the Canon then they would have represented a fairly substantial body of literature, not all of it relevant to a single teaching monk, but nevertheless of significance to scholarly and intellectually-oriented monks with few financial resources with which to acquire individual works just for their own use. In such situations in a monastery or āvāsa (residence) demands would have existed and would have grown for sight and use of these texts that no individual monk could have aspired to meet alone so that there would have arisen pressures, within a monastic institution, for it to acquire the texts on behalf of the monk-users and this requirement could have led to the coming into existence of monastery-based 'centralised' collections.

\section{Possible Sites - Manuscript Collections and Libraries}

An hypothesis from which to mount further investigations is that there can only have been a limited number of sites in Sri Lanka, in this very earliest period, where the early establishment of any types or size of manuscript collections could have been warranted and justified.

From today's perspective, and for our convenience, they can be divided into three groups (although they are not, of course, mutually exclusive) - (1) the major monasteries concerned with the protection and / or development of the Doctrine and the words that conveyed it, (2) those connected primarily with the teaching and learning of the Dhamma, and (3) monasteries, but often cave dwellings, where work involving scholarship, the intellect and extensions of Buddhist knowledge and studies took place. These were often contemplative and meditation sites and were often those in which resided the Lankan bhanakas.

Let us examine these sites in more detail, in these groupings, to discover what, if anything, they reveal about manuscript collections and libraries. 


\section{Monasteries, Doctrine and Manuscripts:}

There are five sites, under this heading, that specifically might be expected to have something to reveal to archeological, as opposed to documentary, researchers. There are the three major Anuradhapura sites associated with the Mahavihara, the Abhayagiri and the Jetavana monasteries. Also in that capital there is the Palace site of the Kings. Outside, to the south (north of present-day Matale), is the Alokavihare Monastery where the first writing down of any Buddhist canonical literature took place and then the later new capital of Polonnaruwa. Scattered around the island there were other relatively remote sites too. These we shall investigate.

\section{1. Mahavihira}

The Mahavihara monastery, the founding and protecting institution of the Theravada Doctrine and its traditions, was early establishment with patronage by many, but not all, later kings. It was commenced during the life-time of Arahant Mahinda and under the patronage of King Devanampiyatissa some time after 246 B.C. Because of its place in Lankan Buddhist development it was wellpatronised and in it resided large numbers of monks - many of them extremely learned and highly-respected for their knowledge and scholarship. Reports, extant today, of visitors at the time attest to these facts. Because of these it early on came to believe itself to be the self-proclaimed guardian of the 'pure' Theravada Buddhist Doctrine, and it developed itself to be so recognized and respected.

If, at some later date, associated with the writing down of the Canon onto palmleafed manuscripts and then, even later, the translation of some of the suttas of the Tipitaka from Pali into Sinhala and as a consequence of these the fast spread of Buddhism and the related speedy establishment of new monasteries and temples, the possibility of the Mahavihara having early on developed a library cannot, at least if only in theory, be ruled out. Indeed as Buddhism became established on the Island, it does appear to have developed a library. By the early part of the $5^{\text {th }}$ century there is little doubt of this fact because by the time of the arrival of Buddhaghosa, he reported that he was working in the Ganthakaravihara. Even earlier Chinese monk-visitors reported on the existence of collections of manuscripts (although it is not known now whether they were collected together into one place to form the embryo of a library collection). Today however, whatever existed then, no longer exists. Where the exact location of any library was is not today known. An archeologist, long involved with these ancient temples' sites, Chandra Wikramagamage, asserts that there are good reasons (although no excavations to date have taken place to provide proof) to believe that it lay to the west of the monastery complex of buildings and the later-constructed Ruwanwelisaya stupa on a site nearer to the bund of the Basawakulama tank. (Private communication to the Author). It is unlikely that it would have been to the east because later (around 249 A.D.) that site was 
abrogated by King Mahasena to the Sagalika Sect and on it they erected the Jetavana stupa and its monastery complex of buildings. To the south lay the awe-inspiring Lovamapasada and just beyond that the Sri Raja Maha Bodhi tree complex. To the north, less than one mile away, was the Kings' palace. It is today considered likely that the original Library's foundations are themselves under the foundations of what is the British-built Archeological Bungalow (itself, unfortunately, also a protected and Listed Building) so that excavations to verify this theory are administratively difficult although, of course, not entirely impossible.

The site of the Mahavihara in Anuradhapura was not the only monastery / vihara complex purporting to protect and propagate the 'true' Theravada Pali Canonical teachings of the Buddha. It had early, after its creation, set about establishing 'branches' elsewhere around the island although most would have been in the island's northern segment given that the country was not yet united under a single ruler based in this capital. Malalasekera suggests "The numerous references made in the Maha-vamsa-tika to these works lead us to conclude that, even at the time of the composition of the tika, there was still [sic] in existence a rich literature of collected works, carefully preserved in the different monasteries, most of them forming part of the Atthakatha, the commentaries to the canonical scriptures." (Malalasekera,1994: 134). Malalasekera identifies the relationship of this tika to the Dipa- and Maha- vamsas (the former $4^{\text {th }}$ century and the latter $5^{\text {th }}$ century) from which they are supposed to have been created. Unfortunately he provides no date but, given that from it in the fourth century, grew the Mahavamsa one can conclude that it could not have been created later than in the A. D. 380's which is an approximate date apparently acceptable too to Geiger - "In Ceylon there existed at the close of the fourth century A.D., that is, at the time in which the Dipavamsa was composed, an older work, a sort of chronicle, of the history of the island from its legendary beginning onwards. . . . This Atthakatha-Mahavamsa existed, as did the Atthakatha generally, in different monasteries of the island, in various recensions which diverged only slightly from one another." (Geiger,1912: $x$ ). What is of importance to us here are Malalasekera's and Geiger's attribution of 'a rich literature of collected works carefully preserved in the different monasteries' by about the A.D. 380's although neither provide either proof for this viewpoint nor, unfortunately, examples of sites where these might have occurred. Significantly however this period (circa 379 to 391) coincides - to almost within a decade or two - with Buddhaghosa's own work in the Ganthakara-vihara. Thus these experts' opinions provide useful corroboration of the fact that collections of manuscripts had begun to metamorphose into recognizable library collections in independent institutions less than 400 years after the Alokavihara writing down. Such an opinion is also attributable (earlier in 1933) to B.C. Law "This book (Mahavamsa-atthakatha) existed in various recensions in the different monasteries of the island, and the authors of the Dipavamsa and the Mahavamsa borrowed the materials of their works from one or other of the various recensions of that Atthakatha" (Law, (2000) 526). 
That they were sharers of the Mahavihara's opinions there can,of course, be no doubt. Interesting also is the implication that as in Europe, around the same period, a scholar knew where the texts were that he wished to consult and that he traveled to them: not as today - in normal circumstances - the texts being moved to the reader!

\section{2. Abhayagiri and Heresies}

The Abhayagirivihara complex comprised twenty-seven individual monasteries spread over many acres to the north of the Thuparama stupa and with large numbers of monks in residence (more than 5,000 according to a report of a visit by Fa Hian, much later in the $7^{\text {th }}$ century A.D., "while there were only three thousand at the Mahavihara" (Gunawardana, 1979; 16 quoting Beal, 1911). It was founded by King Vattagamini Abhaya [who reigned in 103 and again between 89 to 77 B.C (Nicholas, 1961; 341)]. There seems to be much dispute between scholars about Vattagamini Abhaya's actual dates despite Geiger's confident, and extremely unusual, assurance that the Abhayagiri Monastery was founded in the month of March in the year 28 B. C. (Geiger,1912: xxxv). Adikaram uses 29 to 17 B.C., whilst Codrington - not normally much out-of-line subscribes to 88 to 76 B.C (Codrington,1929: $x v$ ). Wickremasinghe places his reign even earlier "(circa 104-76 B.C.)" (Wickremasinghe, 1904-12: 82 ff 11). All of them, fortunately, agree on the length of time during which this king occupied the throne - after its resumption he remained ruler for a total of twelve years. This is significant information because it was in this relatively short period of time that much was accomplished.

This monastery's early history was not without its vicissitudes - founded on a Jain site with its relatively open and liberal policies, although remaining avowedly Theravada - it was to remain throughout its one thousand years' history controversial in the Doctines it espoused. During these centuries it was open to receiving new ideas, concepts and possibly - although not known for certain new texts, related to interpretations of the Buddha's Doctrine. These, of course, were anathema to the traditionalist and conservative Mahavihara monks who for much of the time (but not all of it) remained close to the kings and the Court. They it was who labeled the Abhayagiri heretical (vaitulya) and thus provided the grounds for successive repressions and destruction of manuscripts [about which more later].

There can be little doubt that soon after its creation the Abhayagiri Vihara and its monasteries, for the remainder of its existence as an independent institution, came to represent what the Mahavihara monks believed to be 'heretical' interpretations of the Theravada Doctrine - the so-called vaitulya beliefs. The Abhayagiri, on the other hand, considered itself to have remained within the Theravada tradition throughout - even if with less rigidly conservative interpretations than those of the Mahavihara. As a result of its being open to receipt of these 'outside Sri Lanka' beliefs it exhibited a far more liberal and open 
approach to new ideas that were not always in conformity with the beliefs held south of it that were so unwelcome down the road in the Mahavihara. Here, then, lay the seeds of the future conflicts that were to bedevil Lankan Theravada Buddhism for a millennium until its partial, and temporary, resolution by King Parakramabahu I at the Gal Vihara in 1153 to 1186 A.D.

Many of these 'heretical' beliefs were not only transmitted through dialogue and discussions, but also we know from almost contemporaneous accounts, via manuscripts also. As the visitors, particularly from overseas and especially India and its north, became greater in numbers (as they did) so would the numbers of manuscripts that were brought with them as gifts to the Abhayagiri institutions from overseas. Even to this day a monk, when going on a journey to visit another temple, might take with him a manuscript or a book. The movement in Sri Lanka of manuscripts in the last century and a half, since the earliest catalogues [or more precisely 'place lists'] were compiled, indicate that manuscripts have moved from an original abode in one temple to another with some facility. Comparisons of earlier listings such as d'Alwis' (incomplete) report of 1870 and that of 1876 by Louis de Zoysa (also incomplete in 1876 because also of his death) (Bowden, $2004 ; 208$ ) indicate such movements. Later lists such as K.D. Somadasa's 1956 'A checklist of Ceylon manuscripts' [funded by the Lanka Baudha Mandalaya] and the current and past contents of the Potgul Vihara at Hanguranketa (Bowden, 2004; 198 and Blackburn, 2002; 1) and the existence on many of these manuscripts of three or four inked numbers provides further likely proof of the movements of these manuscripts from one venue to another.

Ironically, perhaps, one of the reasons for Sri Lanka's reputation and place at the centre then of the Theravada Buddhist world was the Abhayagiri monastery and the contribution that, ironically in the circumstances, it made to Sri Lanka's position as the result of its innovative and liberal approaches to, and reception of, less-than-traditionally held Theravada opinions from other nikayas. Adikaram records that "the Mahimsasaka Sect was a well-established school in Ceylon" (p.95) proving his point by noting that "when Fa Hien left Ceylon he took with him a copy of the Vinaya Pitaka of the Mahisasaka School . . . all written in Sanskrit. Very likely these books were taken away from Abayagiri" (94). A later Abhayagiri initiative is represented by King Sena l's construction for it of the Virankurarama which experimented with the possibility of Lankan Theravada monks co-existing together with Mahayana monks - from the Vājirayavāda or Vajrayāna (Rahula,1993; 109).

In history, therefore, the Abhayagiri's importance cannot be minimized nor its reputation for 'open learning' be decried. Its role as a 'gateway' for the arrival of new texts from outside the Island and thereafter their availability to Lankan scholars should not be minimized. An opinion supported later by Buddhaghosa who, although diplomatically resisting quoting sources, indicates their nonTheravada credentials - scholars believe sources obtained from the Abhayagiri - 
by his use of such carefully-selected phrases as keci, apare, eke, ekacce, 'ye ... te' etc. Unfortunately in what manner these gifted texts were stored in the monastery's buildings is not recorded. However one must remember that texts preserved on manuscripts from Indian Mahayana schools would not have existed until well after 32 B.C (the Theravada canonical texts being the first Buddhist scriptures to be committed into writing with suttas from Mahayana authors coming later) - probably some time in the early A.D years but still in timescales that in no way negate the correctness of records of the later destructive activities of certain kings towards the vaitulyas.

Where the library building was [or buildings were] constructed in the vast Abhayagiri monastery complex is not today known nor are there any definite indications, as with the Mahavihara, as to where they might have been located. One could, with some degree of certainty, assume that any library or collection of manuscripts would have been located not adjacent to the stupa but somewhere in what today are identified as the 'Western Monasteries'. The reasons being that this was where monks were learning and being instructed and where there was a hospital, bathing, cooking and eating facilities and other buildings related to domestic and work needs - including the famous and incongruously decorated latrine stones. In such situations might manuscript collections have been assembled. To have placed a library amongst such facilities and adjacent to the kutti's in which the 'professor' monks lived and taught and near to where their students resided would have made much sense. However this is hypothecation in which we shall indulge no further!

Another group of buildings similar to those constituting the 'Western Monasteries' has been discovered two miles east of the cetiya in the village now known as Puliyankulum north of Anuradhapura on the Jaffna road. Bell described, on discovering it, that it was "the largest and most complete monastery of its kind discovered in Anuradhapura . . . the terrace was surrounded by thirty-two cells, each measuring twenty-six feet square" (Gunawardana, 1979; 292) thus according well with the architecture associated with the concept of 'teaching / learning' monasteries. It is dated by an inscription "to the twelfth regnal year of Dappula IV (A.D. 924-935)" (293) which seems to place its construction in the last year of the king's reign. No description of the excavations makes any mention of the existence of a library. Neither have excavations (limited so far) revealed one to date.

There existed other 'off-shoot' fraternities of the Abhayagiri monasterial complexes. These, but very much later, belonged to the Uttaromula and Kappuramulla fraternities - the former having been formed "in the eighth century and soon after the death of Kassapa II (A.D. 650)" (Gunawardana,1979: 287) and the latter "According to the Culavamsa, Dathopatissa II (659-667) built the Kappura Parivena at the Abhayagiri monastery" (Gunawardana; 290). Although disputes exist about its exact founding details, 659 to 667 A.D. provide adequate enough dates for our purpose here which is to attempt to discover whether, and 
which, possessed library collections. Unfortunately no clues exist although supposition and comparisons with elsewhere, would suggest that by these later dates library collections could have come into existence in them.

The later-developed hermitage - the Vĩrāmakurārāma - constructed between the Abhayagiri cetiya and the Twin Ponds in the reign of Sena I (833 to 853 A.D.) "in the Abhayagiri monastery and [who] granted it to the Mahasanghika monks and those of the Theravada school" which, according to Gunawardana (p. 247), is the only reference to the Mahasanghika school in the island. It too is likely to have possessed its own library especially as it was home to 140 monks - the majority from overseas - of four different Mahayana nikaya traditions some of whom, it might be expected, to have brought with them experiences of collection-usage from their respective monasteries in India. They could also have been expected, as was then the tradition, to have brought with them Mahayana-based texts from the different Schools existing there, with which they traveled to Sri Lanka, as gifts for the residences in which they were expecting to live and study whilst in Anuradhapura.

Comparisons of dates for the establishment of these four Abhayagiri 'fraternities' provide clear indications of the strength during a slightly later period (of roughly 276 years - between 659 to 935 A.D.) of the vaitulya factions or, conversely, of the then relative weakness to which had descended the Mahavihara monastery and its off-shoots. [These 'fraternities', in these early 276 years of their establishment and their developments, as apparently insignificant organisations came, by the reign of Parakramabahu, to assume a significance way beyond and above that of their, formerly more famous, three nikayas, expanding from four in number to eight ayatanas and destined to play, as Gunawardana makes clear, major roles before and after Parakramabahu l's 'unification'. (Gunawardana, 1979: 283).

\section{3. Jetavana}

Three hundred and fifty years (approximately) after the establishment of the Abhayagiri the Jetavana monastery came to be established from the Sagalika Sect (founded originally in 312 A.D.) by maverick but energetic King Mahasena, (reigning from 276 to 303 A.D). It originally, like the Abhayagiri, also found too restrictive the Doctrinal and disciplinary positions taken up by the Mahavihara. The Jetavana's establishment had been accomplished not without problems. Sanghamitta (a representative of the so-called vaitulya faction) and a monk from South India, persuaded the king to proclaim that 'whoever gives alms to a bhikkhu dwelling in the Mahavihara is liable to a fine of a hundred pieces of money'. These monks then fled the Mahavihara because Sanghamitta 'seized the opportunity and receiving aid of a minister named Sona, caused the king to demolish three hundred and sixty-four colleges and monasteries." (Adikaram, 1946: 91-92) which, one cannot help but comment upon, is an amazing total, particularly as it is a relatively restricted site close to the palace in the north and 
bounded on the east by the river and the west by the Mahavihara - so this statement may not be entirely correct! Whether they all then possessed libraries or manuscript collections is, today, not known. If all of the 364 'colleges', or the majority of them, did possess libraries or manuscript collections then a record of such large destruction ought to have found a place in world history. It apparently did not. (Knuth, 2006; 223 - 233) Nevertheless, one cannot but harbour some suspicions especially, as with the remains of the Abhayagiri monastery's buildings' destruction, excavations have revealed evidence also of layers of ash and wooden beams where carbon dating has similarly supported a belief that a conflagration did take place in the early 300's A.D.

So this third monastery site (in Anuradhapura), constructed physically so close (actually in what previously had been the garden or grounds of the ancient Mahavihara) to this much older and revered institution, was also believed by that institution's inhabitants to represent the so-called vaitulya opinions. It was the last major nikaya to be established in Anuradhapura (in 312 A.D.) with its complex of buildings.

From this monastery's excavations we already have had light thrown upon some of the unanswered questions regarding manuscripts' existence, the possibilities of libraries existing in these complexes through most useful communications with the architect / conservator Ashley de Vos who, for ten years early in the establishment of the Cultural Triangle Project, functioned as Director Conservation at the Jetavana project and had been involved with the ongoing excavations.

\section{4. Other Anuradhapura sites}

In considering the monasteries and viharas in Anuradhapura associated with the Mahavihara, Adikaram refers to not only the Mahivihara itself but also to the Thuparama and the Cetiyavihara, the Issarasamanarama, modern Vessagirivihara all under the collective name of 'the five great monasteries' (panca mahavihara) thus begging the question of whether they had developed collections or libraries or whether they consisted of only stupas. If they were, structurally, more than this did they have attached to them college and associated fraternity buildings with, of course, the possibilities of each having in its (or its monks') possessions collections of manuscripts? With the resources of the legendary great Mahavihara in relatively close proximity perhaps the need for the development of separate 'branch' libraries was reduced? On the other hand, given the relatively small space - sandwiched between the Mahavihara premises and the river - it may also have been unlikely that any manuscript collections or later libraries that these related monasteries might individually have possessed, could have been gathered together onto this single constricted Mahavihara site.

Again, and it remains hypothesis with no basis of incontrovertible evidence, these large numbers of colleges and other monasteries and the monks instructing in 
them, must have possessed their collections of 'working' manuscripts each belonging to a particular expert monk because monks were encouraged to make copies of manuscripts as it was part of the memorizing and learning process as well as being merit-earning. That in centres of study, where access to manuscripts was relatively easy, the monks there possessed their own personal collections need hardly be in doubt, but where they worked and lived, as many of them did, in remote and inaccessible caves or dwellings far from such resources, it is possible in the best spirit of Buddhism that they shared these in cooperatively-established collections verging on 'centralised collections'. But where, if this did occur, they were located is not now known. Two large sites, now recognized, could likely have been Rithigale and Dimbulagala but about their resources for study and work today nothing, so far, has been excavated.

Other temples in the vicinity of the capital [according to Adikaram - Chapter VII 'Where the faith flourished' [102-124] included the Maricavatti-vihara (today known as the Mirisavatiya) and the Dakkhinavagiri-vihara - home to the Sagaliya Sect and built in the reign of King Saddhatissa (137 to 119 B.C.). (110) Other temples in the proximity of Anuradhapura included the Chatapabbata, the Kalambatittha-vihara, the Kutelitissa Maha-vihara, the Pacinakhandaraji and the Pathamacetiya (which was not a monastery).

In Ritigale (then known as Aritthapabbata) the Makulaka vihara, built by King Suratissa (187 to 177 B.C.), stood at the foot of the mountain. There was a cetiya and, possibly attached to it, a monastery - but these, as yet, have not been thoroughly excavated. At the entry port to Sri Lanka, of Jambukola and most likely named Valika-vihara according to the Sammohavinodani, (attributed to Buddhaghosa as his commentary on the Abhidhamma Vibhanga written in Sri Lanka around 430 A.D. attributes), there was a similar construction. Whether there existed libraries or manuscript collections in any of them today is not known.

It must be recalled that in addition to buildings established by the State or the monasteries or the nikayas themselves the tradition existed of donating spaces usually caves in which monks could reside, work or meditate by ordinary people. Examples exist in many places in the island but the most well-known are in Sigiriya, Rithigale and Dimbulagala, where drip ledges, to this day, in legends bear the names of the donors. That similar donations were made of, or to, libraries or places in which manuscripts could be stored, is unclear but no such legends or references have been discovered to exist. Such 'giftings' would have taken place at dates today unknown but sometime in the period after Mahinda's arrival and the establishment of the first sima and the Mahavihara temple after 247 A.D. and between the removal of the Court from Anuradhapura by King Vijayabahu I between 1055 and 1110 A.D. when the Cola threats to the safety of its inhabitants and those of the three monastery complexes increased. This suggests that places for manuscripts were not considered to be gift-worthy or sufficiently merit-bestowing. Manuscripts in a similar situation (but later on in time 
in Europe) were considered to be rare artifacts, of great value and were greatly valued and protected. What, therefore, were the cultural differences between a later Europe and an earlier Sri Lanka that led to these very different perceptions of their significance?

\section{Libraries and Manuscripts - the move from Anuradhapura to Polonnaruwa}

To Polonnaruwa in his reign King Vijaybahu (1055 to 1110 A.D.) moved the Anuradhapura civilization and all its appurtenances to where he and his successor King Parakramabahu I (1153 to 1186 A.D.) re-established the Court and the monks in physical circumstances and accommodation far in excess of the standards of those enjoyed in Anuradhapura. That the manuscripts, despite their probable value, were also transported - although not particularly heavy they would have been bulky in the extreme - cannot be reliably assumed. Many may have had to have been left behind to face the dangers represented by the invaders into Anuradhapura. If they could not have been moved to the new capital of Polonnaruwa where they could have been suitably housed, then they would have been left to destruction That they were moved - or not moved - is also not known. No references exist to such major upheavals. If they had been saved and moved the precise locations, of where they were stored, are not today known even had these been at the time noted. These facts would suggest that there is a strong likelihood that they were not moved or, if they had been, not in sufficient quantities to have merited any note being taken of the event. Although much of the above is conjecture, that now requires archeological evidence and more facts to turn it into incontrovertible history, the questions themselves are not conjectural - they are the legitimate questions that any scholar or Librarian should ask.

\section{5 Elsewhere}

Moving southwards Adikaram identifies many other sites of monasteries and temples [for which lack of space in this article denies detailed examination]. He examines these in the most useful detail from Kalyani (the present Kelaniya and Mutwal) to those in the hill country - Malaya as it was then known. He comments on the fact that probably even in the earliest days a monastery existed on Sumanagiri (today's Sri Pada) that pre-dated the writing of the Mahavamsa (in mid-fifth century). In today's Badulla there existed the Mutiyangana vihara. Another monastery, today its location not identifiable, was the Pangura vihara in Hatthibhogajanapada - mention is made of it in the Papapancasudani Buddhaghosa's commentary on the Majjhima Nikaya. In further detail does he examine those in Rohana - today's Ruhunu - "Buddhism was introduced to this region during the very first year of Mahinda's arrival in Ceylon." (Adikaram,1946; 115). Two monasteries are known today - the Tissamaharama-vihara that "held a position in the southern half of Sri Lanka which corresponded to that held by the Mahavihara in the northern half" also coupled with the fact that "The monastery was a very prosperous one". This would suggest that manuscript 
collections existed there - an opinion supported also by its comparatively great distance from the northern centres of learning. This is, however, conjecture. Dutthagamini's birthplace - Mahagama - then an ancient city too had a monastery. Elsewhere in Ruhunu there was the Ambariya-vihara probably near Mahagama. "Fifteen miles north-east of Tissamaharama lie the ruins of the Cittalapabbata-vihara built by King Kakavanna Tissa" a brother of Devanampiya Tissa who reigned about 250 to 260 B.C.) which, according to Adikaram, "at one time was one of the most flourishing viharas in Rohana." (118) "A monastery not far from Cittalapabbat was the Kotapabbata-vihara." Both of these would seem to be candidates for the possibilities of having possessed libraries or at least manuscript collections.

Kataragama is represented under its ancient name of Kajaragama with its Kajaragama-mahavihara and where the Kirivehera is reputed to have been founded by Mahanaga (reigning 67 to 79 A.D.) and later enlarged in the first or second century A.D. "In the vicinity of the Cittalapabbata and the Kajarama there was another monastery known as the Gamendavala Mahavihara. Nearby was the Talangara-vihara. Further north is the Dighavapi monastery and cetiya built by Saddhatissa between 137 and 119 B.C. during the reign of his elder brother Dutthagamani. Although roads of a sort would have existed there would have been (as today) much jungle (and possibly very little water) so that travel to consult a manuscript in these and similar areas could have been a hazardous pastime.

The reliability of hypotheses suggesting the existence of collections, although unlikely to have been recognized as early libraries, is just about conceivable before the redaction and the first years of the A.D. centuries. However what is not conceivable is that all the seventy monasteries listed by Adikaram - apart from a few that he identified as important e.g. Tissamaharama, the Tuladharapabhata-vihara and the Kajagama-vihara in the south and the main three Nikayas in Anuradhapura - possessed libraries or even substantial collections of 'books' until immediately after manuscripts became more readily available. It is not unreasonable to assume that as more manuscripts were copied [either in Aloka Vihara but not necessarily only in that venue when, without copyright restrictions, the copying of a work faced only the hazards of the copier's concentration, his carefulness and his patience and where copying was considered to be a meritorious act] the larger institutions very quickly would have begun to develop [although not necessarily supersede] the individual monk's book-boxed collections in favour of more centralized and better coordinated collections. For instance monks dwelling and teaching in Rohana would have been most unlikely to have traveled to the Anuradhapura collections whenever they needed to verify anything. This, then, would have involved journeying along the, what must have been dangerous, Raja Mawatha a distance of at least 350 miles linking Rohana - probably Tissamaharama - with Anuradhapura, via today's Butalla and (according to Geiger) the remains of an elephant track near Bibile, and then a route lying to the east of Rithigale between it and the eastern 
seaboard. Also the descriptions by visitors, such as Fa-Hsien, (quoted by Adikaram) make clear that monasteries like that at Tissamaharama "held a position in the southern half of Ceylon which corresponded to that held by the Mahavihara in the northern half" which would have encouraged their comparable development coupled with the fact that "The monastery was a very prosperous one" (115). Similarly was the case with the Ambariya-vihara which "at one time was one of the most flourishing viharas in Rohana" and Tuladharapabhata-vihara which "was a famous centre of learning in Rohana in the first century A.D" (120). That these institutions existed, remote from the comparative manuscript-riches of Anuradhapura, yet working in those early days before the redaction, without adequate manuscript collections and later, even after Aloka Vihara, without libraries and substantial collections of manuscripts to assist their resident and visiting monks, it is difficult to conceive. Yet not a mention is there anywhere in Adikaran's list nor in Gunawardana of books, manuscripts or libraries (potthakalaya) or archives (ganthakara-parivena). Yet without them and if they did not exist [details not being recorded obviously, because they did not exist] how did the monks achieve the new information in these very earliest of days of the most successful spread of the relatively new Buddhist knowledge, learning and scholarship? How without them could they have acquired them? Could this have been possible?

From these facts revealed by Adikaram I am led to believe - with some confidence based on his evidence - that it is highly unlikely, even after the redaction and, as a consequence, the increased numbers of manuscripts that would have been around, that immediately or even very soon after that event, they all came to possess libraries, or even that they possessed anything more than the few 'working tools' necessary for the teaching responsibilities of the 'professor' monks for themselves and their students - that is with the exception of the Adikaram-named major monasteries. Even before the writing down of the Tipitaka texts it is unlikely that all of them possessed even small collections. Perhaps a 'teacher's guide' here or a Pali / Sinhala glossary there but in the remotest and poorer areas of the country the possession of an original (if copied) manuscript may well have been beyond the financial reaches of the monks and their dāyakas and even perhaps beyond the limits of their knowledge of the existence of such things.

Another 37 monasteries existed and are known from the literatures although their locations have now been lost, as pointed out by Adikaram. These included Bherapasana-vihara and the Culanagalena "It is possible that the Culanagalena was a cave or a group of caves at the Culanaga mountain (pabbata)." (Adikaram, 1946: 120) Others were the Kalavallimandapa (about six hours' journey on foot from Buttala), the Kutimbiya-vihara, the Nagamahavihara, the Tuladharapabbatavihara which "was a famous centre of learning in Rohana in the first century A.D." and the Uccatalanka (first century B.C.) More, today un-locatable, monasteries Adikaram identifies are the Alindaka, Ariyakoti, the Antarasamudda, the Devaputtamaharattha, the Donuppalavapigama, the Galambatittha-vihara, the 
Gaggaravaliya-vihara, the Girivihara, the Girikandavihara, the Hatthikucchivihara, the Kalhala, the Kanikaravalika-sammuda vihara, the Karanandakola, the Kassakalena, the Khandacela-vihara, the Korandaka-vihara, the Kuurundaka (possibly situated near Mannar), the Kupuvena-vihara, the Kutali-vihara, the Lokantara-vihara, the Mahakaranjiya-vihara, the Muluppalavapi-vihara, the Nagapabbata-vihara, the Pancaggalalena, the Piyangudipa-vihara, the Potaliyavihara, the Pancalamavihara (at the foot of the Sonagiri Mountain), the Sudhamundaka, the Vadhatalanagara-vihara and the Vajagaragiri-vihara. Adikaram sums up "It is clear . . . that Buddhism had by the time that the Commentaries were written, spread throughout the length and breadth of the country" a fact which cannot be denied. Whether this "spread throughout the length and breadth of the country' could be related also to the development and spread of libraries' and manuscripts' collections is not stated. Whether they too possessed collections or embryonic libraries today is not known. Today it cannot be known but - because of lack of references - indications are that (unfortunately) this is unlikely to have been the situation.

Unfortunately Gunawardana in his Chapter 4 'Monastic life and relations with the laity' and the section entitled 'Monks as scholars' (Gunawardana, 1979; 154) follows Adikaram's example [because had he not done so, with his erudite investigations, we might now not know as much as we currently do] although he does on occasion name scholars and refer to their works. Good examples are where he names "Dhatanaga and Dhammamitta are the only scholars of the tenth century to find mention in the Culavamsa" (154) however both of these monks are credited with writing commentaries and not works that might be construed as requiring greater originality in that they had to be conceived from scratch. Similarly in this intellectual rigour was copying, composing glosses on other people's creations acceptable practice - all of these practices being not unusual in this period. Work of increased individual scholarship came later and was represented by Anuruddha, assigned by Malalasekera to the $10^{\text {th }}$ or $11^{\text {th }}$ century but by others to the $12^{\text {th }}-$ so, in our chronology, relatively late but predating and within Godakumbura's Parakramabahu II's literary period. (156) Other monk-authors are mentioned but we shall not detail them here except to note that Gunawardana identifies approximately (because of doubts about duplication of names) sixteen monks. "The reforming activities of Parakramabahu I and the revival of the sangha under his patronage ushered in an era of fruitful scholarly activity." (Gunawardana 1979: 156) Much of this led by Sariputta, previously of Dimbulagala, who had been so instrumental in the success of the unification processes at the Galvihara and who, as a result, had later been provided with the sumptuous house built for him by a grateful Parakramabahu in the new Polunnaruwa Jetavana. The Dimbulagala standards, as we have noted earlier, had been much influenced by the earlier learning of the pamsakulikas and the aranikas. Gunawardana correctly sums up the earliest part of the period "It is evident ... that the literary activities of the period under consideration were dominated by exegetic scholarship. The role of the scholars was one of explaining the scriptures and their commentaries, critically examining the 
interpretations given by their predecessors, and systematically presenting the teachings of the Theravada school" (106) - much as one might expect.

\section{7 Assessments}

Nevertheless if one were to be generous in judgment one should not entirely rule out the possibilities that some of these seventy monasteries identified by Adikaram may have been, or could have been, places where one might, with some confidence, have expected to have discovered clues to the existence of manuscript collections even if not of larger libraries. At this stage our investigations leave us only with numerous lacunae. As a result we are none the wiser and no better informed. Our investigations will therefore, have to be conducted elsewhere i.e. in other literary resources more contemporaneous with the events with which they are concerned such as the vamsas. However the most efficacious would be digging and sifting the earth by archeologists in those Adikaram-identified monasteries that, to this day, still exist [many, unfortunately, still covered by jungles] in order to discover what might lie undiscovered in them.

\section{Teaching and Learning}

These twin functions were all undertaken in the capital by the three 'central' viharas of Mahavihara, Abhayagiri and Jetavana. The Abhayagiri in particular, from the archeological excavations, had possessed extensive teaching and learning areas in what today are known as the Western and the 'Eastern' Monasteries and in the Virankumarama - the last two to the east of the cetiya.

The first two also had related monastery complexes that were established in the vicinity of Anuradhapura and, thereafter, further afield across the Island - the Mahavihara possessed the so-called 'five great monasteries' (panca maha avasas). Although at this period Sri Lanka remained to be united Buddhism speedily gained a following across the entire island and other monasteries (as we have already noted from Adikaram) were quickly established island-wide and especially in those parts that were not then 'united' under the kings ruling from Anuradhapura. Some, especially in the south in Rohana, grew to such an extent that they favourably compared with the Anuradhapura monasteries in size, resources and reputations for scholarship and teaching leading one to suppose that libraries they might possibly have possessed.

Somewhat ironically more information and possible corroboration of facts and situations already outlined above are provided by events that appear from a Buddhist doctrinal position to be unbelievable. I refer to book burnings. The burning of 'books' cannot take place unless there are collections of manuscripts ready to hand that were required to be burned. 


\section{Book Burnings}

Despite all the apparent virtues and benefits to Sri Lanka emanating from the Abhayagiri it constantly ran up against opposition that in some instances manifested itself in ways far removed from the Buddha's philosophy of majjhima padipada. For instance, in the reign of King Voharikatissa (269 to 291 A.D.) "The Nikayasangraha (a work by Jayabahu Dharmakirti dated in the $14^{\text {th }}$ century) informs us that in the reign of this king, the dwellers of the Abhayagirivihara put forward the Vaitulya Pitaka as the true teaching of the Buddha. According to this Chronicle the Vaitulya Pitaka was produced in the time of king Asoka by heretical brahmanas called Vaitulyas who had assumed the guise of monks to destroy the sasana. ... Hearing this, king Voharaka Tissa appointed his minister Kapila, proficient in all branches of learning, to investigate the matter. Kapila gave his verdict that the Vaitulya Pitaka was not the true Doctrine. The king, thereupon, caused the Vaitulya books to be burnt. Though the books were destroyed, the spirit of the heretics remained uncurbed." (Adikaram, 1946: 90-91). 'Suppressing the Vetulya-doctrine and keeping heretics in check by his minister Kapila, he made the true doctrine to shine forth in glory" (M-v; XXXVI 41).

That there had been a large-scale burning in the Abhayagiri environs there can be no doubt. It is attested to by Ashley de Vos [reference personal correspondence between him and the Author] who recalls excavating and discovering - between 1982 and 1990 - thick layers of ash and coal found in the lower layers and within them remains that were identifiable as timbers possibly from the roofs of buildings. Dr. Mohan Abeyratne (Head of Research in the Central Cultural Fund from about this period) also confirms, from personal observation, these findings. As the result of carbon dating, he is able to attribute the event to the third century A.D. although he is unable to confirm that any of the ashes came from the burning of manuscripts. Given the thickness of the layer he believes that had manuscripts been a part of that burning then there must have been extremely large quantities of them to produce such results. This suggests that, although manuscripts may have been included in the conflagration, whatever had been the reason for it, it is unlikely that these could have been in such large quantities nor could manuscripts' destruction be the sole reason for the burning. Nevertheless the carbon-dating indicates that the burnings satisfactorily correspond with the period of Voharikatissa's actions. Known facts thus point to this king making history in Sri Lanka by being - possibly - the first ruling monarch to be responsible for burning 'books'.

However this may not have been the first example of such radical opposition to 'vaitulya' incursions. An earlier one might have occurred during the reign of Kuncanaga between 193 and 194 A.D. This event is not so explicitly described thus casting doubts as to its veracity. Voharika Tissa's acts are, in comparison, well described. Unfortunately he was not the only king to indulge himself in this manner. The second [or third depending on one's perception of Kuncanaga's act] unchallengeable event was that of Gothabaya (253 to 266 A.D.) who 
excommunicated and banished the monks in the Abhayagiri (M-v xxxvi 111-2). The third [or fourth] took place in the reign of that somewhat maverick king Mahasena - when he imposed a tax on anyone assisting the Mahavihara monks so that they fled and the monastery fell into ruins and from which act the prime beneficiaries were the Abhayagiri monks! The king later apologized!! But this was followed by another, the fourth [or fifth] and the second in his reign, when his wife directed her wrath at the traditional target of the vaitulya monks (Adikaram, 92).

It may be to Parakramabahu's credit (or to that of Maha Kacana who had come down from Dimbulagala to chair this Council that set out to unite the fractious Sangha) that the king had commanded at the Gal Vihara that the seven ayatannas associated with the Abhayagiri and the one with the Jetavana were not to be subjected [at least according to the Cülavamsa] to the effects of these horrendous 'put downs'. However one might legitimately speculate as to what did actually happen to the manuscripts that each monastery, and much more likely each ayatanna, would by that time [1164/5 A.D.] have collected. That they would not have been welcomed in the Mahavihara's collection can safely be supposed. Nevertheless that there were, from some time around 193 A.D. until some time before 304 A.D. - that is in 89 years - the possibility of four or five situations in which manuscripts might have been destroyed by fire are sad situations to have to recognise.

One must note that Geiger's translation into German, and thence into English, resorts to a gentle generalization using the phrase 'putting down' as translation of the Mahavamsa's "'katvāna niggahana tesana' lit. 'having suppressed them' ( $M$ $v$; xxvi. 112]. However the Pali is most explicit using the gerund 'davā' - 'having burned'. The Nikayasamgraha (composed in 1390 by Devaraksita Jayabahu (Jayawardhana 1994: 23, 42) states 'vaitulya pādā gena davā' - 'having brought the vaitulya doctrine and having burned' leaving no room for doubts.

Nevertheless, if Geiger and Adikaram's allegations are correct that the 'putting down' did involve the burning of monasteries' manuscripts, then that vaitulya destruction provides proof enough of evidence of 'books' or manuscripts being present in enough numbers - in order that they might be burned or similarly destroyed - in the Abhayagiri!! This would suggest with some certainty that collections of written records of vaitulya faiths had begun to be amassed by the time of the first definite book burning by Voharika Tissa between 215 and 237 A.D. Otherwise had these vaitulya concepts still been considered sirti they would have been extant only in the memories of monks so what then would there have been to burn?! These events, ironically, provide proof enough of a start by this period of manuscripts' collection-building! 


\section{Manuscript Collections and 'Book boxes' and 'Libraries' - some theories}

Exactly how and precisely where, amongst this large proliferation of temples and monasteries across the entire island of Sri Lanka, [as described by Adikaram earlier] were manuscript collections and early libraries likely to have come into existence? As we have already indicated archeological evidence is almost nonexistent and so authoritative opinions and comments in response to these two questions have to be severely limited. Nevertheless we are fortunate enough to have views and opinions of archeologists like Chandra Wikramagamage and architects like Ashley de Vos and scientists like Dr. Mohan Abeyratne to draw upon. Similarly because no libraries' sites have been unearthed comments on sites have scarcely arisen - that is with the exception of one architect who has developed some interesting and challenging theories founded on what he has observed and learned from his earlier archeological Anuradhapura excavations.

Ashley de Vos, not a librarian but today a leading Sri Lankan architect [who previously worked for ten years in the early days of the 'Cultural Triangle' Project, especially at the Jetavana site] has developed some fascinating theories which deserve the most careful consideration.

He considers the issues from a very different stand-point to previous scholars. Instead, for instance, of taking the earlier librarian's positions of assuming that 'there must have been' libraries or manuscript collections in the major temples or, alternatively, simply ignoring the subjects, as apparently did the earlier nineteenth and twentieth century European scholars, he commences his considerations by describing, as an archeologist and an architect, what would have existed as the primary and essential parts necessary to constitute an early monastic building complex in this period - namely $3^{\text {rd }}$ to the $5^{\text {th }}$ centuries A.D.- in Anuradhapura. He suggests that they "consisted of a stupa, an Image House, a Bo Tree Shrine, a Chapter House, residences for the monks, refectory, bath house and similar buildings" [arguing that even today these remain standard requirements for a typical temple]. The one difference between now and this past, he maintains, was that the standard monk's residence then was similar to what would be an individual college with a 'professor monk' in residence [similar, one might suspect in some respects, even now, to the older colleges in the universities of Oxford and Cambridge.] As proof he evidences the Jetavana monastery complex [built in the 23 year period between 276 and 304 A.D.] in which twenty-eight such complexes have been identified by archeologists. The later Abhayagiri's 'Eastern Monastery' complex is said, by Bell, similarly to have been constituted with at least thirty-six individual 'college' type buildings. Physically, in the Jetavana excavations, it has been discovered that each 'college' "consisted of two high walled-in areas entered through a gate house. There was a formal entrance and a side entrance. The first space consisted of bath houses etc. The second walled-in space was through another entrance which contained the panchavasa or five avasas. The chief priest's kuti, would have been in the centre, and the four pupils' kutis in the four quarters. 
There were in total about twenty to twenty-five pupils. The high walls prevented those outside to look in and those inside to look out. Learning was by repetition. The Vinaya is very clear that anyone learning a different aspect of the Dhamma should study that aspect only with those studying the same. Understandable because this method led to no confusion. It is my thesis that each college taught one aspect of the Dhamma. The chief monk of a particular college was an expert in a particular aspect. This could be also confirmed by the different types of objects found in the different colleges. The seven gold leaves of the Prajnaparamitta sutra were found next to the round building in the south western quadrant of the Jetavana monastery. One college had Hindu statues etc. The expert monk had his private library in a box or clay pot. This would confirm that each college had its own specialized library. He also had his own private shrine within his space. Pupil monks moved from college to college studying a specialized aspect of the teachings. Centralised libraries would become possible in the smaller monasteries. Jetavana in its day was said to have supported 2000 or so monks." (Personal communication between de Vos and the Author).

De Vos continues by suggesting that the relatively modern concept of a 'central library' had not been developed in the monasteries of the early Anuradhapura period and that instead "Each teacher had his own library, carefully stored in a box. The books [manuscripts] were related to one aspect of the Dhamma. And teaching was by constant repetition. A scholar monk was in charge of a college. Therefore each college had its own library. I personally don't think that there was a concept of a centralized library but there may have been exceptions. The modern temples have a centralized library, but then they are not monasteries. Many of the theories being propounded today are based on today's narrow experience." (de Vos' personal communication with the Author). These are interesting and challenging theories most worthy of extremely careful examination. (de Vos, 1990 and 2003. Pichard and Lagirarde - referred to by de Vos).

That each teacher possessed his own private 'library collection' contained in a box (or a clay pot) that traveled around with him is entirely tenable. A box would seem more practical for a book or rolled-up palm-leaf manuscripts but a clay pot would hardly serve for a book - but this artifact was not yet in existence - but for a soft manuscript (without wooden boards) it would have been sufficient.

What is strange from all this is the paucity of references to these monks 'private' collections and to the receptacles in which their manuscripts were held. Apart from de Vos' reference to the pot containing the golden plates on which were inscribed a Mahayana Sutra text and used for worship from the Jetavana [and this was much later because it has been ascribed to around the $9^{\text {th }}$ century] nothing else seems now to exist. This artifact anyway is hardly likely to have been a 'working texts' because it would have been too expensive for any monk to have been able to afford and it would hardly have been an object designed and manufactured for practical usage. Much more likely its purpose would have been 
for worship i.e. in a Potgul Vihara-type construction or it was to have been a present to the Jetavana from someone with enough financial resources to have had it created. However this does not mean that the theory with regard to the book boxes and clay pots is wrong it just indicates any lack of proof that it is correct. But, then, in Buddhist Studies, that is nothing new!!

However that these boxes or pots represented 'private collections' accessible only to the owners and their pupils is not likely to have been the only and correct situation. One reason relates to the Pathimokkha (the rules in the Vinaya) that lists the three sets of robes and sandals and its case, a knapsack, a firegenerator and other belongings (Rahula, 1996; 192) that a monk could possess. This also makes clear that the other six items that a monk can personally own his alms-bowl, water-strainer, fan and umbrella, needle and thread and a note book - exclude any references to manuscripts and containers for them. (Panabokke, 1993; 34). Even though a monk may have possessed manuscripts in his book box this, and its contents, in reality would have been in the joint ownership of the monastery of which, according to sima rules legally and ecclesiastically, he was a member. Secondly the monks (except those in meditative retreats such as Rithigale and Dimbulagala) would have met regularly in and on their way to the refectories - as the inscribed stone at Mihintale and the huge refectories of the Abhayagiri Western Monastery and the Jetavana attest. Given these meetings of the monks so, similarly, would their pupils have met too - especially on their ways to the fortnightly uposatha service. (Panabokke, 1993; 24). Indeed, after the redaction, there is no reason not to believe that the pupilmonks were themselves not engaged in the creation in their individual colleges of manuscripts - given that this copying was understood to be not only merit-earning but also that copying was just another method of learning by repetition. Before the redaction, which only related to canonical texts, it would not have been impossible for the monks to have copied other minor non-canonical works such as the lexicons and glossaries and teaching / learning 'tools' to which Godakumbura and others have referred. That there were, early in existence, institutions or 'colleges' ('avasas') physically separated from the main parentmonastery too is known - witness Adikaram's listing of seventy such monasteries or temples around the island. The possibilities therefore arise for multiplicities of manuscript collections to have existed used as 'working / teaching tools' by the scholar monk / teachers. That in reality they did exist we cannot know because documentation available to us today makes of them no mention.

In the Sri Lanka of that period such practices, however, were not unique. Similar situations developed in other cultures where the scholar traveled to the monk (or other learned person) who had in his possession the manuscript required to be consulted. [The modern concept of the book going to the user, a la Ranganathan, did not then exist.] However that this miniature 'boxed library' was much used if, indeed, the monks were primarily teachers and if teaching was undeniably by 'constant repetition' then these facts beg a question. Why, for the purposes of repetition, were manuscripts required when much of what had to be learned by 
future theras could not be written down because the words or excerpts were from sacred texts and therefore had to be held only in memories? In addition these manuscripts would have not been easy to acquire and when done so would have been of great value; they were, in the majority, the hand-copied Words of the Buddha. Furthermore libraries, or more appropriately, manuscript collections of this sort, could not have come into existence until the manuscripts were created with the Alokavihara redaction around 23 B.C. Some of them, of course, may have assumed the value of something like heirlooms having been earlier copied when the teacher himself had been a pupil and then been passed on to his own pupils - imitating, in a very different context, the concept that lay at the heart of the Thera parampara tradition.

De Vos' challenge to the 'centralised library' concept is tenable, at least in the earliest days, but only until after the Alokavihara redaction. After that it can be reasonably confidently assumed that many more manuscripts, in comparison relatively quickly, began to be created for a period of at least 500 years - until the arrival of Buddhaghosa about 420 A.D. - as Law and Malalasekera have indicated. Buddhaghosa's, and his companions', works would have been unlikely, in the same manner, to have contributed greatly to the quantities of manuscripts coming into circulation in Sri Lanka because, after all, their purpose was to translate from Sinhala into Pali existing atthakathas and return with them to India - even if they did, also in the process, contribute new literature in the course of this operation.

By this time (circa 435 A.D.) one can reasonably assume (although it must be reiterated, with no proof) 'centralized libraries' (of some sort or other) had apparently started to come into existence (although that would not necessarily have made redundant the monks' own 'boxed collections'). The reasoning behind this opinion being that Buddhaghosa's source for his first work, the Visuddhi magga, was the Vimutti magga, which it is alleged was a text certainly not in any collection in the Mahavihara and therefore unlikely to have been moved around in a teacher's book box, but, more likely, coming instead from the Abhayagiri - by implication suggesting that this monastery at least by about 420 A.D. had developed something akin to a 'centralised' library. We also know, of course, that by this time manuscripts already had been brought to the Abhayagiri from northern and eastern India by traveling monks and pilgrims. We know, on reasonably acceptable authority too (for instance from Adikaram), that Buddhaghosa worked with many texts available to him for him to use as the basis for his Pali commentaries. We also know from his use of non-specific words (keci, apare, eke etc) that some of them were derived from nonMahavihara sources. His consultation of varieties of texts would have been most difficult if he would have had to have searched out specific teachers and had had to travel the country to investigate their individual collections for the references that he required - especially if they were not likely to find acceptance with the orthodox Mahavihara inhabitants - who after all, after the test that produced the Visuddhi magga, were essentially his sponsors and employers! 
The development by that period also of centralised collections is borne out too by the reports of visiting Chinese monks, Fa Hsien (around 400 A.D.) and HiuenTsang (circa 637 A.D.) - both of whom visited and took away to China large numbers of manuscripts [in Hiuen-Tsang's case '657 volumes' according to Cranmer-Byng in his introduction to 'The life of Hiuen-Tsang." (Beal,1911; xiv)]. It would seem unlikely that they could have collected these singly from widelydispersed monks' individual private 'working collections' book boxes where the manuscripts would have been considered to have been most valuable materials and not to be parted with. Nevertheless it is possible to contemplate that these visitors might, like pupils, have sat at the feet of the expert monk and themselves copied a text of his that they required although it seems a little unlikely. It is far more likely that these manuscripts were collected from some sort of 'centralised' source - whether that had been a library or a scriptorium 'copying factory' type of institution.

\section{Theories - assessments}

There are though, even more persuasive arguments, supporting de Vos' contentions of the earlier period personal 'book-boxed' collections - although they do not apply to the later period when manuscripts were more readily available and (I contend) the concept of the 'centralised' library had consequently begun to develop. Firstly his theories are founded on considerations of facts from observations made whilst excavating what today still remains in the earth from the past; secondly they are not based on 'might have been', or 'must have been' or 'there probably was' suppositions; but instead are, thirdly, well grounded not only in the two disciplines of archeology and architecture but also founded on social and educational theories of the ways in which pupils, in those days, learned. We know this to have been correct - by repetition. Fourthly, correct because of the way in which the Sangha worked and on the nature of the relationships of monk to pupil or "of the relationship between a novice and a Preceptor" [and vice versa] - as supported by Panabokke (1993; 31) where "A Preceptor was moreover supposed to develop a paternal attitude towards his charge ... Subsequently the Preceptor was elevated to a higher status, where he was responsible for the entire spiritual standards of the pupil and was the person responsible for presenting him for ordination. .... Another feature in this aspect of training was the appointment of an Acariya (Teacher) to act as a substitute for the Preceptor ... [and he] at a later date came to assume the role of an instructor of Dhamma." The fifth reason - to believe that de Vos' theories are correct - is that the monasteries were well-structured organizations very early in Sri Lanka, almost from the time of King Devanapiya Tissa ploughing the very first sima furrow to create the first avasa. "As a result of the delimitation of precincts by boundaries, the avasas now appear to be isolated and independent units. Each bhikkhu came to be identified as a particular member of an avasa, and he enjoyed all benefits and privileges that accrued to the particular avasa in which he resided." (Panabokke,1993; 24). So, sixthly, that they, then, were places of learning and, founded on each avasa; that they were 'college-based' learning 
institutions also echoes harmoniously with what [little] we know for certain, not about Sri Lanka, but the bhanaka structures that existed pre-Mahinda in northern India. There the leaders of the earliest groups were Ananda, Upali, students of Sariputta, Mogallana and Mahā Kassapa immediately after the Parinibbana of the Buddha and the First Council. We have some theories [if not actual knowledge] of the ways [although we can only guess at them] that the Buddha's words were considered and classified and brought together into suttas, the manner in which the suttas were collected together to create the nikayas and thereafter the texts analyzed and then synthesized to produce the seven books of the Abhidhamma Pitaka and, almost as an off-shoot of these processes, the creation of some of the atthakathas. The very frameworks of the construction by the early bhanakas of the nikayas with their subject / discipline based classifications of the Words lent themselves to the teaching procedures suggested by de Vos - namely that pupil-monks attended a 'college' specializing in a particular nikaya and having mastered this text then moved on to a similar process with another text. It is an opinion upheld, in a slightly different context, by Andrew Skilton in his "A Concise History of Buddhism" when he writes "As already indicated, individual monks and lineages of monks specialized in the memorization of a particular Agama, suggesting that single collections may have been seen as complete and adequately authoritative in their own right". (Skilton, $1994 ; 83$ ). The 'lineage of monks' reference [for instance for the Vinaya commencing with Upāli, the first Vinayadhara, and continuing with his successors Dāsaka, Sopaka, Siggava, Moggaliputta Tissa, Caddavajji etc (Prebish, 2011; 6)] accords entirely with our assertions of the significance in a time when texts were not committed to writing and in the oral-transmission period when the ācariya / sisya parampara and the Theravada parampara systems were the only methods of reliably passing on information and knowledge from one generation to another. Related to this is the seventh argument that the 'college-like' lay-outs of the monasteries - even though they were dissimilar to the orthodox Mahavihara school - and the thirty-odd buildings that comprised each of the 'Western' and 'Eastern' monastery complexes, as well as the later Jetavana site, all indicated an environment in which collections of subject-relevant manuscripts could have been usefully gathered together to provide easy access. In similar manner, too, the larger monasteries, like the Mahavihara and later both the Abhayagiri and the Jetavana temples established and possessed, 'off-shoot' subsidiary monasteries and / or temples where the same practices could well have prevailed. These facts are well known and reliably documented (see the vamsas, Adikaram and Ranasinghe). These all indicate that de Vos' theories chime well with these situations. Eighthly, any suggestion that out of nowhere, with no traditions before them from which examples could have been learned with regard to the creation of what de Vos calls 'central libraries', these sprang into existence is a nonstarter. The histories of the growth of libraries elsewhere in the world attest to the fact that the great libraries and collections that we know today started small and grew in their development. Such an example is the library of the Sorbonne that by 1338 A.D. [long after the period with which we are here concerned] only possessed 338 'carefully chained' reference books and 1728 documents for loan 
even though its university had been in existence since 1150 A.D. - the period of Parakramabahu I. (Man, 2006; 316). Also the Mongol Hulagu in 1257 (less than one hundred years later) "had destroyed Baghdad (the centre of the famed Abbasid Caliphate) [and] had built a massive observatory in Maragheh (just south of Tabriz on the road to Tehran) ... and with a library of four hundred thousand volumes" (Thubron, 2007; 316). There is no reason or proof to believe that this process could have been too much different in the $2^{\text {nd }}$ to $5^{\text {th }}$ centuries in Sri Lanka - although evidence from documents and proof from archeological findings unfortunately do not provide the proof that we should so much have liked to have had.

Ninthly and tenthly, and penultimately, there remain de Vos's two contentions "that monasteries were places of learning, of scholarship and not meant to be pure repositories of knowledge. The role of Aluvihara may have been to disseminate knowledge to a larger number of scholars. Not just to make collections. The collections that the Chinese monks took back may not have been six hundred different books but they could have been many copies of the same." (de Vos' personal communication with the Author). With these two contentions one has to disagree. The first suggests that learning takes place without 'books' - today that is equivalent to 'educational [and librarianship] heresy'. Even in those days of rote-learning manuscripts were necessary [de Vos concedes this] but that monasteries were not repositories of knowledge seems to fly in the face of accepted wisdom about the 'learning / teaching' roles of these Buddhist 'colleges'. If monasteries were not the repositories of Buddhist knowledge where, alternatively was this to have been found, and what functions then remained for these institutions? As primary functions the collecting of manuscripts, I concede, was not a priority but that, as a consequence of the learning / teaching processes, collections, akin to library collections, did not accumulate I cannot agree.

Regarding the Chinese monks' acquisitions one only need ask why would a monk want to wander from one monks' individual collection to another to collect and then lug over the seas, up and down mountain passes between Sri Lanka and China, multiple copies of the same text when it could so easily be copied, as we know did happen in vast numbers, on its arrival into China. Hiuen Tsang circa 629 A.D. deposited in his temple in China "the books of the Great Vehicle, which he had brought from the West, including 224 Sutras, 192 Sastras, 15 works of the Sthavira School, including Sutras, Vinaya and Sastras; the same number belonging to the Sammitiya School; 22 works of the same character belonging to the Mahīsisāka school; 67 books of the same character belonging to the Sarvastivadin school; 17 works of the same character belonging Kasyapiya school; 42 works of the same character belonging to the Dharmagupta school; 36 copies of the Hetuvidiya sastra; 13 copies of the Sabdavidyā sastra, althogether 52 fasciculi, comprising 657 volumes, carried upon twenty horses" (Beal, 1911; 214-6). The vast and wealthy collections in China today, of Indian and Sri 
Lankan-created manuscripts, some of which now no longer exist in the countries of their creation but only in China, clearly support this assertion.

Finally [and eleventh] one cannot ignore the known fact, concerned with education and the role of the temple in it, namely, that even in the very earliest days of the establishment of Buddhism in Sri Lanka during Vattagamini's reign (89 to 77 B.C) a great debate had arisen concerning the functions of monks and the Sangha. The Sangha -members had divided between the monks supporting 'pariyatti' [teaching] and those believing that 'patipatti' [practice] were the primary functions of the Buddhist clergy. The former believed it was to teach and in order to do that to engage in learning whilst the latter believed it was to concentrate on the practice of Buddhism - hence the physical divide that came about between monks engaged in meditation and learning and accumulating new knowledge from studying the Buddha's teachings [as did the bhanakas in India in the very earliest days after Parinibbana], in forest hermitages like Ritigale and Dimbulagala, and others, whilst in the opposite camp were the monks interested, as their priorities, in the spreading of the Dhamma amongst lay-persons. That both were engaged in learning / teaching there can be no denying. However the former were after new knowledge and that can best arise [adopting the concept that new knowledge is built on the shoulders of that which has gone before] from the wisdom of forebears [the poranas and the acariyas] - later that becomes available from its recording in manuscripts - hence the consequential conclusion that some monasteries would have had to shoulder the role of 'repositories of knowledge' with all the developments consequent on that.

This dispute was not to die without leaving a residue that later was to always colour Sri Lanka's Sangha history and its Buddhist development in that the outcome changed forever the priorities as made clear by the Buddha although [interestingly] without altering a single relevant word of the texts in the Tipitaka. It is no better exemplified than in Gunawardana's study of early and medieval Ceylon in his 'Robe and the Plough'. These disagreements, and similar arguments around the same period, led to the creation of the Arranikas of which Gunawardana states "Though their numbers do not appear to have been large, the appeal of the forest-dwellers, attitudes and style of life won prestige and influence for them among the laity and endowed them with the authority to play a dominant role in the reforms of the sangha during the reign of Parakramabahu I." (Gunawardana,1979; 350). Apparently too they were creative writers responsible for works that contributed to the later development of Sinhala literature. Sympathetic to their objectives were those monks who chose to join the pansakuliya sect and others who followed this ascetic and independent path of 'rag-robe wearers'. They had been known in Sri Lanka, according to Gunawardana from at least the $2^{\text {nd }}$ century B.C. (Gunawardana,1979: 41) quoting the Sahassa-vatthu-pakarana (49) although at that time they had no known affiliations with any specific nikaya. They were ascetics who wore robes made of rags and were meditative monks living in hermitages remote from the laity who devoted themselves to scholarship so that they produced some of the 
future "leading scholars and hierarchs among the sangha during the twelfth and thirteenth centuries" (Gunawardana,1979: 46) including from Dimbulagala Kassapa, assisted by Sariputta, both of whom were instrumental in Parakramabahu's cleansing and unification of the Sangha in 1164/5. Thereafter they made large contributions with their works [and those of their pupils] to Lanka's literary heritage. It was they who took themselves off from major monasteries and temples and went to reside and work in caves, on mountains and into jungle retreats and other remote places. The most significant sites then in Rajarata were located at Mihintale, Rithigale, Dimbulagala and Sigiriya. During their existence, and Gunawardana suggests that around the $10^{\text {th }}$ and 11th centuries references to their existence simply vanished so what happened to them is not known, but in between they seemed to have occupied well-respected positions within the Sasana. They are recalled here [although chronologically in a much later period] because of the possibilities [and they are only 'possibilities'] that in order to assist them in their earliest days in establishing themselves with their studies they too had accumulated manuscript collections. Facts are now not known.

One might have confidently expected that another consequence of bhikkhus giving priority to learning might have been a better appreciation of the importance of writing down the Tipitaka and later translation of some suttas of the Canon from Pali into Sinhala so that with greater ease and availability of manuscripts for teaching and learning, a better appreciation of their importance in these practices and consequential expansion of manuscript collections into the development of libraries might have occurred. This, however, was not to be.

Ashley de Vos' arguments are most persuasive: monk's small personal 'working' collections were early established and numbers of them increased after the 23 B.C redaction facilitated the creation of greater numbers of manuscripts. That these did not exist in the earliest days but all that did then exist were 'working tools' in the form of small 'working' collections of manuscripts in individual 'book boxes' of the 'professor monks' - and not libraries - can be supported. From these small beginnings did the larger 'centralised' collections develop as Buddhist knowledge and education and manuscripts to support these activities spread so that eventually over the next 450 years and certainly by the time Buddhaghosa started work circa 420 A.D., an unknown number of 'centralized' libraries had come into existence.

If de Vos' theory about teaching bhikkhus in 'college'-style situations is correct [and there is no reason to believe that it is not] then there would also have come into existence a number of collections of literatures relating to either, or both, the heretical subjects being taught and the different schools of Mahayana Buddhism from which the instructing monks belonged. To have housed such 'heretical' documents in a primary 'central' library might well have been considered to have been too impolitic: to have housed them in the associated fraternities in the Abhayagiri might have been less troublesome! 
In Adikaram's identification of seventy monasteries where monks in this early period between - a little later than 247 B.C. and 150 A.D. i.e. only a brief period of 400 years - lived, worked, prayed, meditated, taught and probably studied at least to the degree necessary to be able to preach and answer questions from their faithful, it is not possible, as always, to surmise un-challenged from this lacuna in information, whether they too possessed collections of manuscripts. However, given what has been discovered, it is likely that these 'private libraries' [the monks' book boxes of 'working' documents] were in existence to varying degrees. Otherwise how could these activities, particularly the last, have been undertaken without recourse to manuscripts [and the places in which they were stored and housed]? It would, therefore, appear not to be unrealistic to suggest that in this period [more than half of which, of course, pre-dates the writing down in manuscripts of the Tipitaka] that collections, of varying sizes, were either in existence or would have come into existence. As so often, facts are there none, to provide an unchallengeable answer and to complete these gaps, Nevertheless from these snippets of information that we have been able to glean and assemble and the theories about how education took place between the bhikkhu I samanera students and their 'professor' monks, one can reasonably assume that a monk instructing without reference to any work would have been a more unusual than normal practice despite the prevalence of learning by rote.

\section{Book Boxes Metamorphosed into ‘Centralized' Libraries}

We have already noted [and been convinced by] the persuasive arguments of Ashley de Vos. As a consequence we have supported his opinions that favoured the creations, by individual monks, of their private collections. The references to the sheer numbers of monasteries and temples, of manuscripts and the amount of literature about which we have firm knowledge (referring, for instance to Godakumbura, Adikaram and Gunawardana) and snippets of information culled from the vamsas and other literary sources give the lie to the generallypropagated propositions that 'libraries' in Sri Lanka early came into existence. At a later stage, however, that some 'centralisation' of manuscript collections did take place to create the 'centralised' libraries that existed in other parts of the world by that same period, must now be investigated.

If these theories and observations of the earliest collections not being 'libraries' ('centralised' or otherwise) but individual monk's collections of 'working tool' manuscripts held in book boxes or pots are accepted so that at some later date the 'centralized libraries' developed from them then three fundamental questions arise. (1) In the unfolding processes of the transmission of the Tipitaka in Sri Lanka can any precise dates at which these larger 'centralised' libraries began to develop and take on the attributes of 'central libraries' be attributed? (2) What would have been the characteristics of a 'central library'? (3) What were the changing circumstances that encouraged these developments from individuals' collections of 'working tools' into larger collections held 'centralised' in libraries? 
Dates and specific facts or references in the literature or lithics today as to when and in what manner these developments took place there are none. There are, however, other related events the dates of which we can use with some sense of reliability, that provide useful and as reliable clues to dates as we have a right to expect.

The first of these events must have been the production of scripts for manuscripts without which the need for libraries [of any sort] just would not have existed. That is undeniably logical. Nevertheless those non-Canonical texts were being created before the writing down of the Canonical texts that found their ways into the individual monk's 'book boxes' there can be but little doubt. It was, after all, for these 'professor monks' to facilitate their teaching and by these selfsame 'professor monks' themselves, that these texts had in the first place been created. As we have indicated Godakumbura identified the sorts of materials that would have been created - glossaries ('ganthipada') primarily into Sinhala from Pali, translations into Sinhala from Tamil, Malayalam and Telegu, lexicons and dictionaries, 'textbooks', 'teachers guides' etc. in Sinhala to elucidate upon canonical texts existing in Pali that large numbers of monks are thought unlikely to have been able to fully comprehend - these are opinions supported by Law and Gunawardana.

K. R. Norman had advanced cogent arguments to support the view that although texts may not have been recorded in writing in their totality the skills of writing were not unknown even if during this period they had not yet been associated with religious or literary works. Its use was not unknown to the Emperor Asoka's court around 247 B.C. - for instance the famous letter from Sri Lanka's King Tissa to the Emperor seeking permission to apply to himself the title 'Devanampiya'. In such a context Norman suggests (Norman,1994: 79) that two scripts were in use in that Court: the origins of the Brahmi script that can be traced to the Indus Valley around 2,000 B.C.E. Because traders operated throughout the Near East, and Middle East, via the famous Silk Road, it could not have been unknown during the time of the Buddha and the period thereafter. The other was the Karosthi script "derived from Aramaic script used by administrators in the Persian Empire" but the sources from which it can be traced going back to the Semitic family of languages." (Whitfield, 2004: 108).

A few years later writing skills are known to have been applied in Sri Lanka by the Court for the maintenance of accounts, reports of regal years and the upkeep of the armories. Traders, particularly those in contact with overseas merchants, would have had to possess such skills as would the ksatriya and vaisya classes many of whom had become recruits into the priesthood thus bringing with them these skills. It also would have been surprising if aides memoires to difficult texts [although not the sacred words of the texts themselves] had not been jotted down by monks in the course of their teachings and instructions. 
Anyway important is it to note that nowhere in the Vinaya rules are there references to prohibitions [or encouragements] connected with writing. (Norman, 1994; 81).

As a fact we also know that in his composition of the 'Visuddhimagga' Buddhaghosa had access to the 'Vimuttimagga' which, being a non-traditional Theravada text (in the eyes of his employers - the monks in the Mahavihara) scholars suggest may have come from the Abhayagiri although some have suggested that it may have originated in the Mahavihara itself (Nanamoli,1956: $x x v i i i)$. Buddhaghosa mentions no specifically-named donor thus implying that it came not from the cell of an individual monk but from either the Abhayagiri as a corporate body (or the Mahavihara) thus suggesting the existence then in $420 \mathrm{~A}$. D. of some sort of centralized collection of manuscripts. Similarly in his works Buddhaghosa (as would any qualified scholar) refers to his sources amongst which are the poranas and acariyas and of course documents. When these documents represented what he judged to be heretical opinions he used imprecise words to denote sources such as 'keci', 'apare', 'aññe', 'itare', 'ye ... te' etc leading one to the assumption that they came from sources closely allied with vaitulya doctrines - in other words again the Abhayagiri monastery. This also implies that the source was not from an individual monk's collection but from a corporate body - again indicating by that time the existence of a centralize collection of manuscripts. Such a theory is much in accord with Panabokke's opinions regarding the ownership by an individual monk of material things and the habit then of material objects in monasteries being collectively owned by all those inhabiting it. (Panabokke,1993) The final evidence [if that it can be called that] comes from the fact that Buddhaghosa himself referred to his work place as the Ganthakara Vihara or 'repository temple'. (Malalasekera,1994; 82)

Although no precise date can be attributed to the metamorphosis of small manuscript collections into what one might recognise as 'centrally-arranged' organization's libraries, one can make assumptions [from these facts] about which we can be reasonably certain with regard to, if not specific dates, at least the period of years in which small manuscript collections of individual monk's 'working tools' metamorphosed into what we have categorized as 'central libraries'. An additional argument in favour of such a theory is that it is difficult to envisage or to comprehend how the extremely fast development and spread of Buddhism in Lanka could have taken place at the speed that it did without recourse to manuscripts and therefore also to the collections of these texts into libraries of some type. A view further supported by the speed with which burned vaitulya texts were apparently replaced.

The idea that some of these small 'working collections' - particularly those in the kutis of the two main monasteries of the Mahavihara and the Abhayagiri - formed 'centralized' collections akin to libraries sometime before Buddhaghosa's access to them circa 420 A.D. although when precisely that development commenced, is a more difficult issue to address. That these changes were not single dateable 
events one can be certain about. That they were the results of developmental growth and slow changes one can be fairly certain. These could not have started before 23 B.C. and the creation of the first Buddhist canonical manuscripts. However developments could have speeded up in subsequent years as the numbers of available manuscripts increased. These activities also would later have received a spurt of energy with the translation into native Sinhala of the previous Pali texts after the reign of Buddhadasa between 340 to 368 A.D. One can therefore hazard a guess that it was the increasing size of individual's collections, increased demand for access to them and the application of Vinaya rules observing these changes perhaps with some unhappiness at the growing numbers of manuscripts in individual monks' possessions [in contradiction of the patimokkha rules governing ownership of robes and various belongings and comparative corporate ownership] that, between them, encouraged the collectivization of monasteries' individual holdings into some sorts of centralised collections. Although no precise date can be calculated these collections would have evolved sometime in the 450 years between about 23 B.C. and 420 A.D and towards the end of that period, and not its beginning. In it one may surmise one could have seen the coming into existence of these first 'centralised libraries' metamorphosed from the small individual monk's collections of 'working tools'.

As a practicing, professional Librarian it would have provided much pleasure, as well as elucidation, to know or even guess what these 'centralised' libraries, once they had come into being, looked like. That they would not have provided for centralized 'services' can be safely assumed because the very concept of 'service' would not have come into existence. Today a definition of 'centralised' implies the centralization and coordination of book-stocks and holdings (via a union catalogue in pre-IT days), services, management, user services, staff training and relationships locally and nationally with other similar contiguous services. That, one can be certain, is not what anyone had in mind when the term 'centralised libraries' came to be applied in these contexts. That they would have in no way resembled what today we would recognize as 'central libraries' one can be certain. One can be certain, also, that what de Vos intended to convey [by his use of the phrase] was the idea of collections of different manuscripts in a single institution with some degree of organization of them by subject or discipline instead of, or as well as, the individual collections of 'professor monks', in each avasa, independent of, or affiliated in some way to, a major monastery. In other words - the natural development of, and expansion into, 'centralised' manuscript collections based on a single institution instead of, or to reinforce, the individual monks' book-boxed collections in de-centralised avasas. Such a concept makes sense and although, as usual, there is no proof, there are these more than adequately-based clues to support such a hypothesis. 


\section{Māhavāmsa, Cūlavamsa - investigations into 'Libraries' and 'Manuscripts' etc.}

Now let us turn to a more detailed analysis in documents and lithics of what has gone before. To do so [in best librarianship practice] we have selected seven related terms to use for searches. These search-terms are - libraries 'potthākalaya' and repositories - 'ganthākara-pirivena'; manuscripts 'hattalekhana' / books - 'potthaka'; librarian - 'ganthālaya adhikāri'; scribes / writers - 'lekhaka' and writing - 'lekhana'.

Our sources for what follows have been the Cūlavamsa, the Rājāvaliya (composed sometime in the $16^{\text {th }}$ century) the Nikāya Sangrahaya (1390 A.D.) and the Saddhammarathnayakara (also circa 1390) all created centuries after the events with which they were concerned and all consulted by Ranasinghe (2006). Detailed literature searches of the two prime sources - the Mahâvamsa and Cülavamsa - reveal the following:
a. libraries (potthalāya)
\}
b. repositories (ganthākara-parivena) \} - references $\times 4$
c. manuscripts (hattalekhana) / books (potthaka) x 5 references
d. librarian (ganthalaya adhikāri) $\times 2$
e. scribes / writers (lekhaka) \& writing (lekhana) x 9

- making a total of 20 references only in the 938 pages that make up the the Maha- and Cula-vamsas (in Geiger's 1912 and 1929 translations) and covering the period 246 B.C. to 1164 A.D. which is a period of 1,410 years.

Geiger, it should be noted, never uses the word 'libraries' but other terms that can be construed as referring to libraries pointing out that "Several official titles are formed with the word potthakin, namely: bhandara-, adi-, mula-, and jivatapotthakin ... According to its origin 'potthakin' has reference to an official who in some sphere or other has to do with book-keeping, the making of lists and inventories." ( $C-v$ xxix). When making reference to 'scribes' Geiger points out that "The Government Scribe is called likewise lekhaka." Even with the most liberal and wide interpretations of the words 'libraries' - potthakalaya; 'repositaries' ganthākara-parivena; 'manuscripts' / 'books'; 'librarians' and 'scribes' / 'writers' and very generous interpretations of the contexts in which these and other related references appear in vamsas and related documents little enough interest it is clear had been manifest in them until Geiger and other early scholars were awakened to these subjects. In these earliest documents specific references to manuscripts [and 'books'] and libraries are almost nil and to librarians per se there is not a single mention!

Specifically investigating the Mahāvamsa [because, according to Ranasinghe (2006)], it makes only two references (36:41. 37: $5-7)$ and that history, it must be recalled, was written between 460 and 478 A.D. which is half way through this 
period that we are investigating, these two references [if they relate to Geiger's 1912 English-language edition] are not directly connected with manuscripts' collections, both refer to suppressions of the vaitulya nikaya and the implications of these acts. This vamsa was, therefore, compiled with hindsight and from secondary sources rather than from the actual witnessing of events as was the practice of Herodotus - the 'Father of History'. The Dipavamsa contains a single reference (22: 41-42) and the Nikaya Sangrahaya (12-14) and the Saddharmarathnakaraya only one each (p. 306). Both of these, anyway, were created centuries later than the events - in the early $13^{\text {th }}$ century.

\section{Detailed results of investigations}

It is has been important to clearly cite references to these details, where they are recorded in the vamsas [and other works], in order to obtain a correct perspective on the apparent relative un-importance [or otherwise] of these materials, buildings and people.

The famed Inscription at the entrance to what had been the Abeyagiri's Cetiyagiri monastery in Mihintale (dated between 975 and 991 A.D.) lays down in the greatest detail the responsibilities of the Sangha to its members and theirs to their brotherhood. However no mention does it make of these subjects. Lands, buildings, jewels, flowers, robes, foods, drinks etc [from these texts] are lavished on monks and visitors. Lists, in copious details, there are of officials associated with the works and management of monasteries which include keepers of the relic caskets, to servants collecting white lotuses and others harvesting blue lilies, to painters of the dagaba and to even lower caste society-members like barbers and washer-men - but to librarians or keepers or collectors of manuscripts and the buildings that they might have occupied there are [as indicated] almost none.

Even, when the construction of buildings such as the Lovamahapaya (Brazen Palace) and the Mahapali refectory are described in detail, libraries do not figure. Indeed given the levels of merit achieved by the monks who would inhabit that nine-storied building strange is it that a defined space for a library or a collection of manuscripts was not considered necessary for them in the early developmental stage or, thereafter, during the processes of its numerous repairs and reconstructions. One has to again ask the question - why this apparent ignorance or overlooking of libraries? If manuscripts in larger numbers were beginning to come into existence why no references to these changing circumstances of the monks [who would have been their primary users] in the vamsas written by their brethren; why no mention of the places in which they were to be kept? The questions are serious. The lack of answers betokens a major lack of interest.

The first clear, and comparatively significant reference, to what can be suspected to have been a 'library' is that by Buddhaghosa who, when referring to the place 
of work in which he created the Visudhimagga referred to the Ganthakara-vihara which, from its name suggests space set aside for manuscripts [gantha = 'to tie, knot, bind, fasten together i.e. books put together - or composed' (Rhys Davids, Stede 'Pali Text Society's Pali-English Dictionary, 1999; 243)]. 'Then dwelling in the Ganthākara-vihāra which lies far from all unquiet intercourse' ( $C-v$ I, 37. 243) Buddhaghosa completed his work This reference, however, was composed more than four hundred years after the first writing down onto manuscripts of the canonical texts [that we have asserted was the first step in Sri Lanka to the creation of collections of working tools that could then have metamorphosed into libraries as we might today recognise them].

The next references of any major significance occur another 500 years later when the Culavamasa asserts that Parakramabahu created library buildings in his new [as yet relatively un-excavated university / monastery to the northeast of the Gal Vihara] Jetavana monastery where it is stated that "For the seventy-five parivenas (he built) as many long pāsādas with charming figures (painted), two storeys high; (further) one hundred and seventy-eight small pāsādas, thirty-four gate-towers and two houses for books ... (he built) the Tivamka house for the Tivamka image .." (C-v II 78 37). These constructions were therefore, at the earliest, created after 1161 [when Parakramabahu for the third and last time had been consecrated king] and before his death in 1186 A.D.

Associated with these acts was the king's assistance to Ven. Mahakassapa'a pupil Sariputta who assisted in the Gal Vihara unification of the Sangha exercises and was rewarded by Parakramabahu. This monk had also been a pupil of Venerable Sumedha who was the principle of the Alahana Pirivena in the Jetavana Vihara (Pali Sahitiya; 249-252; 260-262). This great seat of learning, built by Parakramabahu, consisted of 'eight three-storeyed residences for the eight ayatanas and a separate residence for Ven. Sariputta. Furthermore it comprised nine three storeyed image houses seventy-five two storeyed residences, one hundred and seventy-eight smaller residences, two libraries, a vatadage, three preaching halls, a stupa, an alms hall, eighty-five kitchens, one hundred and seventy-eight toilets and other requirements." ( $M-v$; 505-508 and Jayawardhana, 1994; 144). Also in these last years Parakramabahu, to his credit when restoring the damages brought about by fighting in Rohana, restored "Thirty-seven stupas, twenty-two Bodhi Tree terraces, two hundred and seventyfour large image houses, one relic temple, seven temples for images in the recumbent posture, forty caves and four brick houses; four long pasadas, six three-storeyed pasadas, twenty-nine sermon halls and three cloisters, one hundred and twenty-six dwelling houses, one hundred and twenty-eight houses for books and four rest houses for guests." (C-v. II 79 76). An interesting question to which no answer can be deduced is - how many manuscripts might have been accommodated in 128 'houses for books'? 


\section{Summary and Conclusions}

The belief that 'libraries' [as defined today - see above] existed in the period of approximately 600 to 650 years from 246 B.C. until the arrival in 400 A.D. and the works of the 'Great Commentators' before the last's departure circa 550 A.D., obviously cannot be substantiated by proven and / or recorded facts. This belief cannot be correct. In its place one can believe that instead, what slowly developed into existence were small collections of manuscripts used for teaching and learning purposes in the monasteries in which these activities were being conducted. At first these were likely to have been manuscripts containing little of what today we would classify as 'literature' [that was to develop from these works much later] instead they were 'working documents' intended to assist both teachers and students in their teaching and learning processes - much as a classroom collection used to exist in schools and some departments in higher education institutions. Many would have been (Godakumbura) texts translated and / or adapted from other peoples' works in languages other than Sinhala either from Pali or more likely from southern Indian languages such as Malayalam, Telugu and Tamil. They were not canonical texts. That would have been the situation that the facts - such as we know them now - indicate to have existed up until approximately 23 B.C. when the restricting influences of vimukti practices were leavened by the need to preserve the Words that made up the Teachings from loss from the memories of the monks whose job it was to preserve them. This was done by writing them down in the Alokavihara around 23 B.C. Thereafter, in the following 400 years, it is possible to assume that the 'working collections' saw major expansions as newly-written canonical texts came to be copied onto manuscripts in ever-greater numbers and as some suttas came to be translated from Pali into Sinhala - these then eventually to join those texts already included in the monks' 'kuti' working collections. Given that the Vinaya in no place sanctions the personal ownership of manuscripts one can as a consequence safely assume that as the numbers of manuscripts in each individual monks' 'working collections' expanded and as the numbers of monks with collections necessary for their teaching and learning practices in individual monasteries also increased the monks resident in them ensured the corporate holdings of these working collections by emphasizing the corporate ness of ownership and thus individual collections metamorphosed into what today we might recognise as 'centralized' libraries' collections.

These were slow indigenous Sri Lankan developments spread over hundreds of years and almost entirely unique in their creation owing very little, if anything, to developments elsewhere in the world. 


\section{REFERENCES and CITATIONS}

\section{Primary and Secondary sources}

Anguttara Nikaya Atthakatha. London: PTS

Cūyavamsa - being the more recent part of the Mahāvamsa. Translated by Wilhelm Geiger and from the German into English by C. Mabel Rickmers. In two parts. Part I. [Original date of publication 1929]. Delhi. Asian Educ. Services. 1992.

Cūlavamsa - being the more recent part of the Mahāvamsa. Translated by Wilhelm Geiger and from the German into English by C. Mabel Rickmers. In two parts. Part II. [Original date of publication 1929]. Delhi. Asian Educ. Services. 2003.

The Mahāvamsa or the Great Chronicle of Ceylon. Translated into English by Wilhelm Geiger. [Original date of publication 1912]. Delhi. Asian Educ.

Services.1986.

'Nidanavagga'. The connected discourses of the Buddha. A translation of the Samyutta Nikaya. Translated from the Pali by Bhikkhu Bodhi. Boston. Wisdom Pubs. 2000.

The Path of Purification (Visuddhimagga) by Bhadantacariya Buddhaghosa. Translated from the Pali by Bhikkhu Bodhi. Boston. Wisdom Publications. 2000.

\section{Critical works}

Abeynayake, Oliver. (1984)A textual and historical analysis of the Khuddaka Nikaya. Colombo. [No publisher].

Abeynayake, Oliver. (2000)"Sri Lanka's contribution to the development of the Pali Canon." Buddhism for the new millennium. London. World Buddhist Foundation. 163-183.

Adikaram, E. W. (1946) Early history of Buddhism in Ceylon, or "State of Buddhism in Ceylon as revealed by the Pali Commentaries of $5^{\text {th }}$ century A.D." (Thesis submitted to, and accepted by, the University of London for the Degree of Doctor of Philosophy). Dehiwala. Buddhist Cultural Centre. 
Beal, Samuel. (1911)

The life of Hiuen Tsiang by Shaman Hwui Li with an introduction containing an account of the works of ITsing. London. Kegan Paul, Trench, Trubner. 1991. Delhi. Asian Educ. Services. 1998.

Blackburn, Anne M. (2002) "Notes on Sri Lankan temple manuscript collections." London. JPTS. XXVII. 1-59.

Bodhi, Bhikkhu (1993) Introduction. 'The Question of King Milinda; an abridgement of the Milindapaňha edited by N.K.G. Mendis.' Kandy. BPS. 1-13.

Bowden, Russell. (2008) 'The Canon in Ceylon: Sinhala Literary Heritage and Libraries' Developments'. Buddhism: Contemporary Studies. Selected papers from $3^{\text {rd }}$ International Conference, Sri Lanka Association for Buddhist Studies (SLABS). Editors Sanath Nanayakkara, Russell Bowden. Colombo. SLABS. 2010.

Bowden, Russell. (2006) The Processes of Transmission of the Buddha's Dhamma: a Survey and Analysis from Parinibbana to the Third Buddhist Council. Thesis submitted for Degree of Master of Philosophy. Postgraduate Institute of Pali and Buddhist Studies. University of Kelaniya. Sept 2006.

Bowden, Russell. (2004) "Access to resources for Buddhist Studies in Sri Lanka." Journal of Buddhist Studies. 2. (Jan 2004). 198-240.

Cartledge, Paul. (2004) Alexander the Great: the hunt for a new past. London. Macmillan.

Codrington, H. W. (1939) A short history of Ceylon with a chapter on Archeology by A.M. Hocart. Delhi. Asian Educ. Services. 1994.

de Silva, M. U. (1987) "The growth of libraries in Sri Lanka during the nineteenth century." Vidyodaya, J. Soc., Sci., I. 2. July 1987. 43-77.

de Vos, Ashley. (1990) "A typology for a monastic building in Anuradhapura." RAS Journal. 
de Vos, Ashley. (2003)

de Vos, Ashley (2003

Feather, John.

\& Sturges, Paul. (1977)

Forde, Helen. (1997)
The Buddhist Monastery. A cross-cultural survey edited by Pierre Pichard and Francois Lagirarde. Paris. Ecole Francaise d'Extreme-Orient. 38-58.

The Buddhist monastic architectural tradition of Sri Lanka.

Epigraphia Zeylanica being lithic and other inscriptions of Ceylon. Edited and translated by Don Martino de Zilva Wickremasinghe. London. Govt. of Ceylon. OUP. 1912-1934.

International encyclopaedia of information and library science. London: Routledge.

"Archives." International encyclopedia of information and library science edited by John Feather and Paul Sturges. London: Routledge. p. 13.

Godakumbura,C.E. (1955)Sinhalese literature. Colombo: Colombo Apothecaries.

Gunawardana, R.A.L.H. (1979) Robe and plough. Monasticism and economic interest in early medieval Sri Lanka. Assocn. of Asian Studies. Tucson Univ. of Arizona Press.

von Hinuber, Oskar. (1996)A handbook of Pali literature. Indian Philology and South Asian Studies. Albrecht Wezler and Michael Witzler eds. vol. 2. New York: Walter de Gruyter.

Jayawardhana,Somapala.(1994)Handbook of Paliliterature. Colombo: Karunaratne \& Sons.

Knuth, Rebecca. (2006) Burning books and leveling libraries. Extremist violence and cultural destruction. Westport: Praeger.

Kularatne, Tilak. (1975) "History of libraries in Sri Lanka." Libraries and People. Colombo Public Library 1925 - 1975. A commemorative volume edited by Ishvari Corea. Colombo:Public Library.

Landau, Thomas. (1958) Encyclopaedia of Librarianship. London: Bowes \& Bowes.

Law, Bimala Churn. (1933)A history of Pali literature. Varanasi: Indica Books. 2000. [First published 1933]. 
Lock, Reginald Northwood. (1958) "Printing" Encyclopedia of Librarianship edited by Thomas Landau. London: Bowes \& Bowes.

McGarry, Kevin. (1997) “Library".International encyclopedia of information and library science. Edited by John Feather and Paul Sturges. London: Routledge.

Malalasekera, G.P. (1983) Dictionary of Pali proper names. 2 vols. Delhi: Munshiram Manohalal. First Indian edition.

Malalasekera, G.P. (1924) The Pali literature of Ceylon. Kandy. BPS. 1994. [Originally pub. RAS 1924]

Man, John. (2002)

The Gutenberg Revolution. The story of a genius and an invention that changed the world. London. Review.

Man, John. (2006) Kublai Khan. From Xanadu to Superpower. London: Bantam.

Minayeff, J.P. (1886) The Gandha-vamsa. Ed. by J. P. Minayeff. II. 1985-7. London: JPTS. 54-81.

Nicholas, C.W. (1961) A Concise History of Ceylon - from the earliest times to the arrival of the Portuguese in 1505 by C.W. Nicholas and S. Paranavitana. Colombo: Ceylon University Press.

Panabokke, Gunaratne. (1993) History of the Buddhist Sangha in India and Sri Lanka. Colombo: Postgraduate Inst. of Pali \& Buddhist Studies. Univ. of Kelaniya.

Piyadasa. T.G. (1985) Libraries in Sri Lanka. Their origin and history from ancient times to the present time. Studies on Sri Lanka. series 1. Delhi: Sri Satguru Pubs.

Prebish, Charles. (2011) Cooking the Buddhist Books; the implications of the new dating of the Buddha for the history of Early Indian Buddhism. Journal of Buddhist Ethics. editor@buddhistethics.org - [retrieved Feb 2011.]

Rahula, Walpola. (1996) What the Buddha taught. Rev. ed. Dehiwala: Buddhist Cultural Centre.

Ranasinghe, R.H.I.S. (2006)Parani Lankawe potgul sampradaya. Library tradition in ancient Sri Lanka (from $6^{\text {th }}$ century $B C$ to $13^{\text {th }}$ Century AD). [Author published]. 
Skilton, Andrew. (1994) A concise history of Buddhism. Birmingham: Windhorse Pubs.

Somadasa,K.D. (1959-1964) Lankave puskola poth namavaliya. Part I. Colombo. Dept of Cultural Affairs. 1959. Part II Colombo: Dept of Cultural Affairs. 1964.

Thubron, Colin (2007) Shadow of the Silk Road. London: Vintage.

Whitfield, Susan \& Sims-Williams, Ursula eds. (2004) The silk road. London: British Library.

Wickramagamage, Chandra. (2004) Heritage of Rajarata. Major natural, cultural and historic sites. Colombo: Central Bank of Sri Lanka and Rajarata Development Bank.

Wickremasinghe, Don Martino de Zilva (1904-12)

Epigraphia Zeylanica being lithic and other inscriptions of Ceylon. Edited and translated. 4 vols. London: For the Govt of Ceylon.

Windisch, Ernst. (1908) Buddha's Geburt und die Lehre von der Seelanwanderung. Leipzig.

Winternitz, Maurice. (1907) History of Indian literature. 2 vols. Delhi: Motilal Banarsidass. 1981. 